Western Washington University

Western CEDAR

8-10-2000

\title{
Continuous Sampling of Hydrothermal Fluids From Loihi Seamount After the 1996 Event
}

\author{
Craig L. Moyer \\ Western Washington University, craig.moyer@wwu.edu \\ C. Geoffrey Wheat \\ Hans W.Jannasch \\ Josh N. Plant \\ Francis J. Sansone
}

See next page for additional authors

Follow this and additional works at: https://cedar.wwu.edu/biology_facpubs

\section{Recommended Citation}

Moyer, Craig L.; Wheat, C. Geoffrey; Jannasch, Hans W.; Plant, Josh N.; Sansone, Francis J.; and McMurtry, Gary M., "Continuous Sampling of Hydrothermal Fluids From Loihi Seamount After the 1996 Event" (2000). Biology Faculty and Staff Publications. 18.

https://cedar.wwu.edu/biology_facpubs/18

This Article is brought to you for free and open access by the Biology at Western CEDAR. It has been accepted for inclusion in Biology Faculty and Staff Publications by an authorized administrator of Western CEDAR. For more information, please contact westerncedar@wwu.edu. 
Authors

Craig L. Moyer, C. Geoffrey Wheat, Hans W. Jannasch, Josh N. Plant, Francis J. Sansone, and Gary M. McMurtry 


\title{
Continuous sampling of hydrothermal fluids from Loihi Seamount after the 1996 event
}

\author{
C. Geoffrey Wheat, ${ }^{1,2}$ Hans W. Jannasch, ${ }^{3}$ Josh N. Plant, ${ }^{3}$ Craig L. Moyer, ${ }^{4}$ \\ Francis J. Sansone, ${ }^{5}$ and Gary M. McMurtry ${ }^{5}$
}

\begin{abstract}
For at least 9 years prior to July 1996, hydrothermal fluids flowed from Pele's Vents on Loihi Seamount, Hawaii. In July-August 1996 a tectonic-volcanic event occurred that destroyed Pele's Vents, creating a pit crater (Pele's Pit) and several sites with hydrothermal venting. In October 1996 we deployed two new continuous water samplers (OsmoSamplers) at two of these hydrothermal sites and collected fluids using traditional sampling techniques to monitor the evolution of crustal and hydrothermal conditions after the event. The samplers were recovered in September 1997, and additional discrete vent fluid samples were collected. The OsmoSampler located along the south rift at Naha Vents captured a change in composition from a low-chlorinity, high-K fluid (relative to bottom seawater) to a high-chlorinity, low-K fluid. These changes are consistent with the fluid cooling during ascent and being derived from several different sources, which include high$\left(>330^{\circ} \mathrm{C}\right)$ and low- $\left(<150^{\circ} \mathrm{C}\right)$ temperature components and a source of magmatic volatiles. The other OsmoSampler, which was deployed on the rim of Pele's Pit at Lohiau Vents, captured warm hydrothermal discharge that originated from a high-temperature source (> $330^{\circ} \mathrm{C}$ ) into which magmatic volatiles were added. During the deployment, thermal and fluid fluxes decreased. At Naha the transport of heat and chemicals was decoupled. The chemical and thermal evolution of hydrothermal fluids after the event on Loihi is consistent with previous models based on events that have occurred along mid-ocean ridges. The event at Loihi clearly had an effect on the local hydrography; however, the integrated effect of chemical fluxes to global budgets from similar events is uncertain. Chemical fluxes from similar events may have a global impact, if ratios of chemical (e.g., $\mathrm{CO}_{2}, \mathrm{Fe} / \mathrm{Mn}, \mathrm{Mg}$, sulfate, and $\mathrm{K}$ ) to thermal anomalies greatly exceed, or are in the opposite direction to, fluxes from mid-ocean ridge hydrothermal systems.
\end{abstract}

\section{Introduction}

Changes in the chemical composition of hydrothermal discharge after tectonic-volcanic events have been documented along mid-ocean ridges [e.g., Baker et al., 1987, 1998; Butterfield and Massoth, 1994; Von Damm et al., 1995, 1997; Massoth et al., 1995, 1998], and a conceptual model has been developed to explain the chemical evolution of venting fluids [Butterfield et al., 1997; Von Damm et al., 1997; Delaney et al., 1998]. However, the timing of this evolution is uncertain. To date, observations of temporal variability in the chemical

\footnotetext{
'Global Undersea Research Unit, University of Alaska, Fairbanks.

${ }^{2}$ Also at West Coast and Polar Regions Undersea Research Center, Moss Landing, California.

${ }^{3}$ Monterey Bay Aquarium Research Institute, Moss Landing, California.

${ }^{4}$ Biology Department, Western Washington University, Bellingham.

${ }^{5}$ Department of Oceanography, University of Hawaii, Honolulu.
}

Copyright 2000 by the American Geophysical Union.

Paper number 2000JB900088.

0148-0227/00/2000JB900088\$09.00 composition of hydrothermal fluids have relied on repeated submersible operations and the collection of discrete samples. Thus, defining the timescale over which variability occurs is limited by the periods between expeditions. While this technique provides some temporal constraints, it does not provide a continuous record of chemical change. A continuous record provides a measure of the changing physical and biogeochemical conditions within the crust and thus is useful in elucidating the temporal scale of transformations in crustal conditions, especially those that influence the pattern of seawater circulation within the crust. A continuous record also allows one to monitor the path of evolution. For example, are changes in crustal conditions continuous or instantaneous? Do these changes result in changes in hydrothermal fluid chemistry that are monotonic or do chemical changes follow a circuitous pattern in response to changes in crustal plumbing?

We have developed a new water sampler (OsmoSampler $(H$. W. Jannasch et al., Long-term in situ osmotically pumped water samplers, submitted to Deep Sea Research, 2000, hereinafter referred to as Jannasch et al., submitted manuscript, 2000)) that allows for the continuous collection of fluid samples. Here we present vent fluid chemical and thermal data collected with two OsmoSamplers and compare these data to data obtained using traditional discrete sampling methods. 


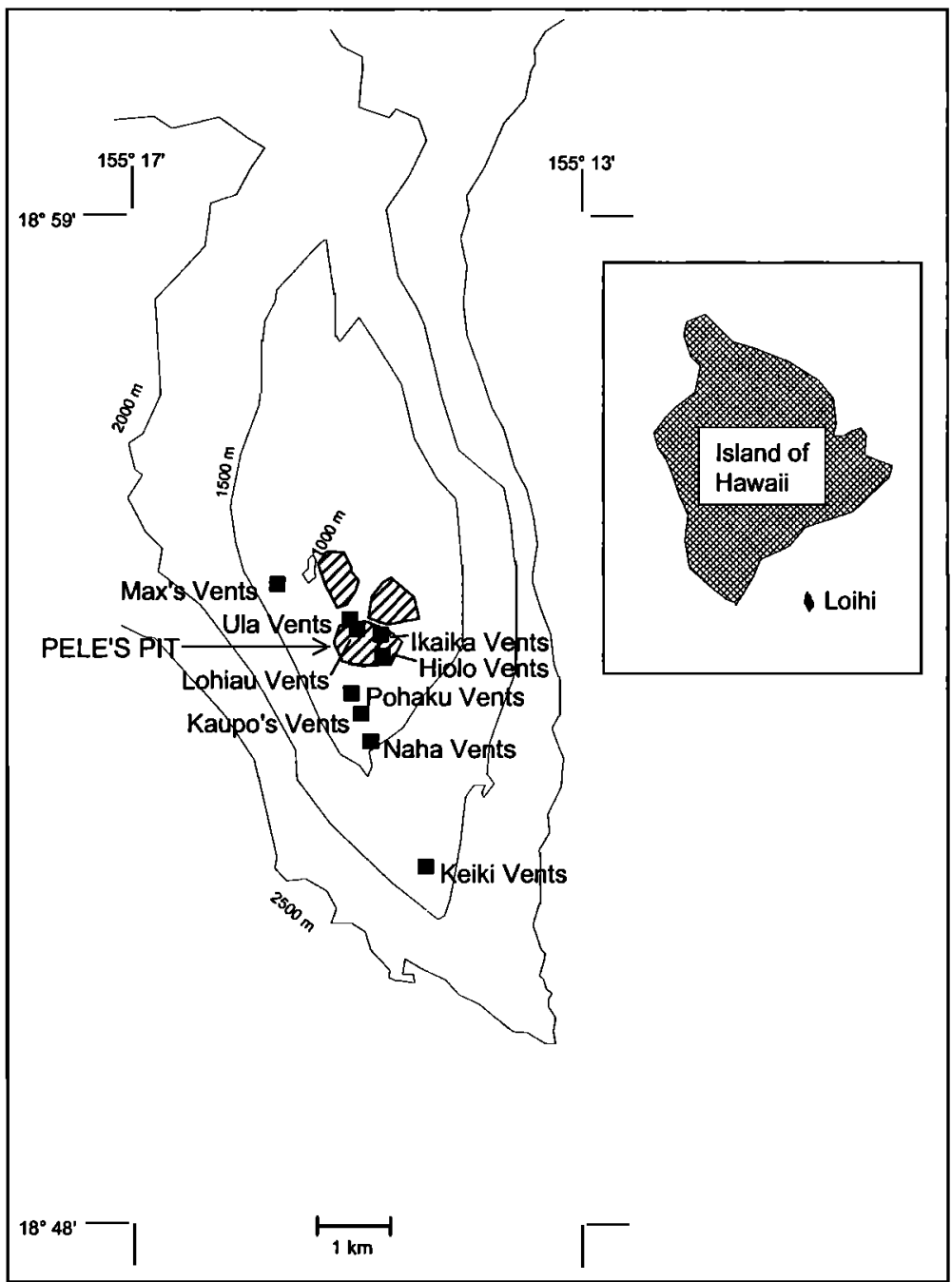

Figure 1. Location of the observed hydrothermal vent sites on Loihi Seamount, Hawaii. Depths are in meters. Shaded areas indicate the summit pit craters.

The samplers, which were deployed from October 1996 until September 1997, were positioned in hydrothermal outflow zones that formed after a tectonic-volcanic event on Loihi Seamount, which is a hydrothermally active, midplate, hot spot volcano located $\sim 35 \mathrm{~km}$ southeast of the island of Hawaii. The event occurred from July 16 until August 9, 1996 and resulted in the formation of a $0.06 \mathrm{~km}^{3}$ pit (Pele's Pit) [The 1996 Loihi Science Team, 1997]. This transformation in crustal conditions altered the pattern of hydrothermal circulation through the seamount, changed the chemical composition of the effluent, reordered the structure of macrobiological and microbiological communities, and resulted in the formation of assemblages of sulfate and sulfide minerals that have previously not been found on the seamount [The 1996 Loihi Science Team, 1997; Davis and Clague, 1998]. Data from the OsmoSamplers and their comparison to data from fluid samples collected using traditional discrete sampling techniques allow us to document the temporal scale of chemical and thermal changes in the hydrothermal effluent. On the basis of these data we discuss changes in the conditions at depth after the perturbation and the potential global impacts of hydrothermal chemical fluxes resulting from such perturbations.

\section{Background}

\subsection{Setting Prior to the 1996 Event}

Loihi, the youngest volcano in the Hawaiian-Emperor Chain, rises $\sim 4 \mathrm{~km}$ above the abyssal plain to a depth of $\sim 970$ $\mathrm{m}$ below sea level (mbsl) (Figure 1). Prior to the tectonicvolcanic event in 1996, the presence of hydrothermal discharge was deduced from chemical anomalies in the water column [Gamo et al., 1987, Sakai et al., 1987; Karl et al., 1988; Landsteiner et al., 1993] and from recovered Fe-rich oxides and smectites [Malahoff et al., 1982; DeCarlo et al., 1983]. These studies led to identifying and sampling sites of hydrothermal discharge [Edmond et al., 1987; Karl et al., 1988; Sedwick et al., 1992, 1994; Sansone et al., 1994, 1998]. Most of the known hydrothermal venting from Loihi Seamount prior to 1996 occurred at Pele's Vents at a depth of $\sim 980 \mathrm{mbsl}$. This site was located just south and west of two pit craters and was destroyed during the formation of Pele's Pit (Figure 1). Pele's Vents were located in an area of $\sim 20 \mathrm{~m}$ by 20 $\mathrm{m}$, and fluids exited from a small portion $(<0.1 \%)$ of this area. Other sites of hydrothermal venting were identified prior to 1996 (Max's Vents at a depth of $1249 \mathrm{~m}$ and Kaupo's Vents at 
a depth of $1234 \mathrm{mbsl}$ ), but the low rate of fluid outflow or the rough terrain precluded the collection of vent fluid samples from these sites. An additional site of hydrothermal venting has been suggested at a depth of $\sim 1800$ mbsl based on chemical anomalies in the water column [Gamo et al., 1987], but the source of this plume has not been identified.

Hydrothermal fluids at Pele's Vents emanated from cracks at the base of boulder-sized pillows and between pillows. These $\sim 30^{\circ} \mathrm{C}$ fluids were sampled in 1987 [Edmond et al., 1987; Karl et al., 1988], in 1990 [Sedwick et al., 1992], in 1991 [Sedwick et al., 1994], and in 1993 [Sansone et al., 1994]. From 1987 to 1993 the magnitude of chemical change was negligible for most chemical species, yet for some species (e.g., total $\mathrm{CO}_{2}$, alkalinity, $\mathrm{Ca}, \mathrm{Mg}$ ), measurable changes did occur. These changes, however, were small (most $<2 \%$ with the largest change $<20 \%$ ) when compared with changes observed after the event (>100\%). In this paper we present chemical data from hydrothermal fluid samples collected in 1993 from Pele's Vents to represent the composition prior to the event. We report these data because they overlap earlier data sets and because we collected and analyzed these samples, thus minimizing any sampling and/or analytical biases.

\subsection{Setting after the 1996 Event}

The July-August 1996 event on Loihi lasted $<1$ month yet consisted of over 4000 earthquakes that were detected by the Hawaiian Volcano Observatory [The 1996 Loihi Science Team, 1997]. This activity represents the largest swarm of earthquakes ever observed at a Hawaiian volcano. About 1 month after the onset of the 1996 event, three dives were conducted with the submersible Pisces $V$. No hydrothermal vents were discovered because the particle load in seawater near the seafloor limited the visibility to $<3 \mathrm{~m}$. Subsequent dives in September 1996 located two sites of active venting, one in Pele's Pit (Ikaika Vents) and the other on the north rim of Pele's Pit (Lohiau Vents) (Figure 1). Unfortunately, no fluid samples were collected on the dive to Pele's Pit, and safety concerns prevented further dives to this site in 1996. In October 1996 we conducted seven dives with Pisces $V$ during which we sampled three sites with hydrothermal venting (Lohiau, Naha, and Pohaku Vents). We also deployed a continuous water sampler (OsmoSampler) at each of two hydrothermal sites (Naha and Lohiau). In September 1997 we conducted five dives and returned to each of these sites. Additional hydrothermal sites (Ikaika, Hiolo, Kaupo's, and Keiki Vents; Figure 1) were discovered and sampled. The depth, maximum temperature, and number of discrete vent fluid samples collected at each of these sites are listed in Table 1.

Geologic settings in which hydrothermal vents were located after the event comprise three broad structural categories: diffuse fracture-controlled vents, diffuse talus-covered vents, and jets of hydrothermal fluids that penetrate a barite-rich base. Diffuse fracture-controlled vents were located along the flanks of the seamount (Naha, Pohaku, Kaupo's, and Keiki Vents). Here fluids flowed from large fractures (e.g., up to 1-3 $\mathrm{m}$ wide and tens of meters long at $\mathrm{Naha}$ ) or between distinct pillows. Venting was patchy and each site covered an area of $\sim 200$ to $600 \mathrm{~m}^{2}$. Similar to conditions at Pele's Vents before the event [Malahoff et al., 1982; DeCarlo et al., 1983], the seafloor at each of these hydrothermal sites, with the exception of Keiki, was covered with a reddish brown nontronite and iron-oxide film that was millimeters to centimeters thick. Many of the cracks from which fluids vented in 1996 lacked any sign of active venting in 1997. For example, the large fracture ( 1 to $3 \mathrm{~m}$ wide, several meters deep, and tens of meters long) at Naha had $19.2^{\circ} \mathrm{C}$ fluid venting from it in 1996 and was dormant on a return visit in 1997.

Diffuse hydrothermal venting through talus was located on a steep slope $\left(\sim 45^{\circ}\right)$ that bounds the rim of Pele's Pit and a near vertical wall that defines the northern extent of the caldera (Lohiau and Ula Vents). This talus blanket was composed of pebble to cobble sized fragments of basalt and was stable. Stability is based on a marker that was placed on a talus slope in the middle of a chute. Even though this marker was in a seemingly perilous position, it did not move for a period of 1 year between repeat submersible operations. Venting also occurred along boundaries between talus and basaltic outcrops. Hydrothermal emissions from Lohiau Vents had maximum temperatures in the range of $53^{\circ}$ to $77^{\circ} \mathrm{C}$ in 1996. The entire venting area was covered with a thin blanket (millimeters to centimeters in thickness) of nontronite and iron oxides in 1996 and a thick blanket (several centimeters) in

Table 1. Hydrothermal Vents Sampled During the October 1996 and September 1997 Dives on Loihi Seamount

\begin{tabular}{|c|c|c|c|c|}
\hline & \multirow[b]{2}{*}{ Location } & \multirow[b]{2}{*}{ Depth, mbsl } & \multicolumn{2}{|c|}{$\begin{array}{c}\text { Max Temp, }{ }^{\circ} \mathrm{C} \\
\text { (Number of Discreet Samples) }\end{array}$} \\
\hline & & & Oct. 1996 & Sept. 1997 \\
\hline \multicolumn{5}{|c|}{ Discovered October 1996} \\
\hline Lohiau Vents & NW wall of Pele's Pit & 1173 & $77(13)$ & $43(2)$ \\
\hline Ula Vents & NW wall of Pele's Pit & 1099 & & \\
\hline Naha Vents & South Rift & 1325 & $23(4)$ & $11(2)$ \\
\hline Pohaku Vents & upper South Rift & 1196 & $17(4)$ & $11(1)$ \\
\hline Maximilian Vents & west flank of summit & 1249 & & \\
\hline Ikaika "Forbidden" Vents & NE floor of Pele's Pit & $1297-1310$ & $200(0)^{*}$ & $112-200(14)$ \\
\hline \multicolumn{5}{|c|}{ Discovered September 1997} \\
\hline Hiolo Vents & SE floor of Pele's Pit & 1288 & & $59(1)$ \\
\hline Kaupo's Vents & upper South Rift & 1234 & & $15(0)$ \\
\hline Keiki Vents & lower South Rift & 1714 & & $25(1)$ \\
\hline
\end{tabular}

* A. Malhoff (personal communication, 1996). 
1997. Lohiau Vents included an area of $\sim 100 \mathrm{~m}^{2}$ from which hydrothermal outflow was focused through $\sim 1 \%$ of the area in 1996. On the basis of visual observations, less than a few percent of the volumetric flow observed in 1996 was evident 1 year later.

Buoyant jets of hydrothermal fluids, with maximum temperatures of $200^{\circ} \mathrm{C}$, have only been located in Pele's Pit (Ikaika and Hiolo Vents). These jets were located within several meters of the wall-floor contact. Much of this venting was associated with barite-rich mounds, which were up to a meter in diameter and several tens of centimeters high. No change in temperature was observed between repeat visits in 1996 and 1997.

\subsection{Sample Methodologies}

Samples of hydrothermal fluids were collected using discrete and continuous samplers. Discrete samples were collected using titanium 750-mL Walden-Weiss (Major) and 3-L Niskin samplers. Before discrete samples were collected, we monitored the temperature for $5 \mathrm{~min}$ at the point of venting or at the opening of a particular Niskin sampler; Niskin bottles were firmly attached to the basket on the submersible. Samples were then collected by either closing the Niskin sampler or by placing the snorkel of a Major sampler in the same location that was monitored for temperature before activating the sampler. Major samplers have a small void ( $\sim 1 \%$ of the total volume) that must be filled with fluid to insure proper performance. We filled this void by priming each of the Major samplers with filtered background seawater collected at a depth of $1000 \mathrm{mbsl}$. Discrete samples from both samplers were filtered immediately upon recovery through $0.45-\mu \mathrm{m}$ polycarbonate filters and stored in a variety of tracemetal clean, high-density polyethylene bottles with and without the addition of $6 \mathrm{~N}$ subboiled $\mathrm{HCl}$. Unfiltered aliquots also were collected and analyzed for comparison.

Continuous samplers consist of an OsmoSampler and a miniature temperature probe (Figure 2). OsmoSamplers use the osmotic pressure that is created across a semipermeable membrane by solutions of differing salinity [Theeuwes and Yum, 1976]. This osmotic pressure drives water across the membrane at a rate that is dependent on the surface area of the membrane, type of membrane, salt gradient, and temperature. Jannasch et al. [1994] used osmotic pumps to deliver reagents into a sample stream for in situ chemical analysis. In contrast, the pumps in an OsmoSampler are used to continuously draw sample through small bore (0.8-mm I.D.) Teflon tubing that is initially filled with distilled water. We used a temperature probe with a resolution of $0.0014^{\circ} \mathrm{C}$ at $30^{\circ} \mathrm{C}$ that was programed to record a measurement every $10 \mathrm{~min}$.

For deployment in a hydrothermal vent the intake for the sample tubing was positioned within a $40-\mathrm{cm}$-long $\mathrm{T}$ handle onto which a temperature probe was attached (Figure 2). A 2$\mathrm{m}$ section of tubing separated the sample intake from the pump to allow the pump to be placed in an area without hydrothermal influence. Great care was given to insure that the pumps were not in contact with hydrothermal effluent because the rate of pumping is dependent only on temperature given an excess of salt on one side of the membrane and distilled water on the other side. Before either of the two samplers were deployed on Loihi, we monitored temperatures at the pumps. Temperatures at the pumps varied by $<0.1^{\circ} \mathrm{C}$ for the two sites on Loihi. An increase of $1^{\circ} \mathrm{C}$ causes the pump rate to increase by $<5 \%$. Thus time stamps for individual samples were

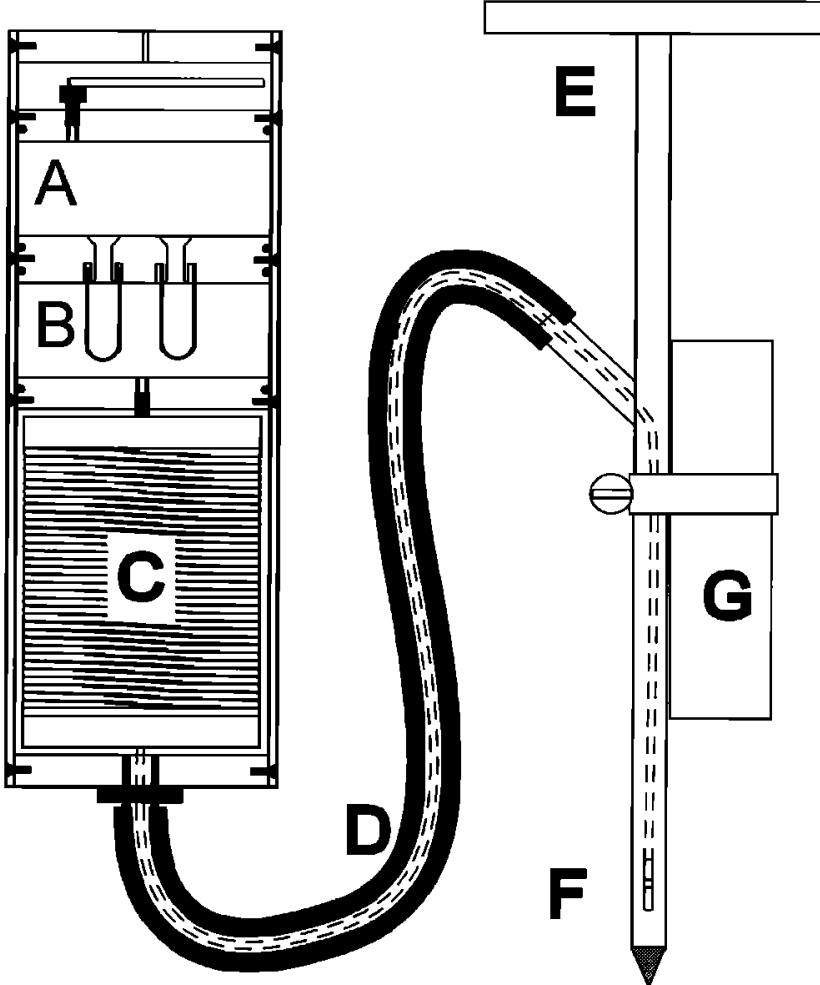

Figure 2. Schematic drawing of the OsmoSampler. A, salt reservoir; $B$, distilled water reservoir with osmotic membranes; C, $200 \mathrm{~m}$ of $0.8-\mathrm{mm}$ I.D. Teflon tubing which is initially filled with degassed distilled water and is used for sample storage; D. 2-m-long flexible tubing within which the tubing from $C$ is connected to $F$, the sample input, thus allowing the pump to remain at near-ambient bottom water temperature while the intake is positioned in a crack through which hydrothermal waters egress; E, T handle for submersible manipulation; and G, temperature probe. The thermistor in the temperature probe is attached to the housing near the sample intake and has a response time of $45 \mathrm{~s}$ and a resolution of $0.0014^{\circ} \mathrm{C}$ at $30^{\circ} \mathrm{C}$. Laboratory tests in which sample input alternated between seawater and altered seawater confirm that dispersion resulting from diffusion and peak smearing is not significantly greater than that expected from molecular diffusion alone [Jannasch et al., 2000, submitted]. Thus a step change in concentration is contained within a single $1-\mathrm{m}$ section of $0.8-\mathrm{mm}$ I.D. tubing after 3 months. Bacterial sheaths formed in $\mathrm{F} \sim 2 \mathrm{~cm}$ from the intake causing a failure in the OsmoSampler at Naha at the junction of $B$ and $C$ and a failure in the OsmoSampler at Lohiau in the sample tubing $C$.

determined by assuming a uniform temperature at the pump. This translates into a uniform rate of pumping for the duration of the deployment.

Chemical data were obtained by retrieving the sampler, cutting the Teflon tubing into 1- or 2-m sections, expelling the fluid from these sections into microcentrifuge tubes, storing the samples in a refrigerator, and analyzing the fluid for chemical species of interest. None of these samples were filtered, and alternating samples were acidified. No sampling or storage artifacts including evaporation of the sample were evident in laboratory tests, with the longest test lasting $>3$ months (Jannasch et al., submitted manuscript, 2000). Tests 
included all of the major ions in seawater and some of the minor ions including $\mathrm{Fe}$ and $\mathrm{Mn}$. Note that $\mathrm{Fe}$ was not problematic in laboratory studies.

\subsection{Chemical Analyses}

Standard potential and colorimetric titration techniques were used to measure concentrations of $\mathrm{Cl}, \mathrm{Mg}$, and $\mathrm{Ca}(1 \sigma=$ $0.1 \%)$. Alkalinity was determined by potentiometric Gran titration on $20-\mathrm{mL}$ aliquots of discrete samples $(1 \sigma=0.5 \%)$ and on $0.5-\mathrm{mL}$ aliquots of samples from the OsmoSampler ( $1 \sigma$ $=2 \%$ ). Few samples collected with the OsmoSamplers were analyzed for alkalinity because the analysis consumed the entire sample. Chlorinity, $\mathrm{Ca}$, and alkalinity measurements were conducted at sea. In addition, some $\mathrm{Mg}$ analyses were completed at sea. Repeated and additional $\mathrm{Mg}$ analyses were completed ashore and confirmed the lack of evaporation, even with a small sample size of 0.5 to $1 \mathrm{~mL}$. We also used standard inductively coupled plasma atomic emission spectrometry (ICP-AES) for determining concentrations of $\mathrm{Mn}, \mathrm{Fe}$, $\mathrm{Sr}, \mathrm{Si}, \mathrm{Ba}$ and $\mathrm{B}(1 \sigma \sim 2 \%)$, ion chromotography for sulfate ( $1 \sigma$ $=2 \%)$, and atomic absorption techniques for $\mathrm{K}(1 \sigma=2 \%)$. Only the ICP-AES analyses were conducted on acidified aliquots.

\section{Results}

In this section we present the deployment history of the two OsmoSamplers that were deployed in 1996, one at Naha Vents and the other at Lohiau Vents. We compare data from the OsmoSamplers with data collected using traditional discrete methods to show that OsmoSamplers provide an unbiased continuous record for many dissolved chemical species. We include data from Pohaku with data from Naha because (1) Pohaku is the only other site from which we acquired chemical data in 1996 and 1997, (2) both sites are located along the south rift, and (3) the chemical compositions of hydrothermal effluents from both sites are similar.

\subsection{Deployment of OsmoSamplers (Naha and Lohiau)}

We deployed an OsmoSampler at Naha $\sim 3 \mathrm{~m}$ from the main fissure that lies parallel to the south rift. The sample intake was placed in a crack that split a basaltic pillow. Hydrothermal fluids that emanated from this crack in 1996 had a maximum temperature of $22.8^{\circ} \mathrm{C}$ using the probe attached to the submersible. This temperature is $\sim 2^{\circ} \mathrm{C}$ warmer than the initial temperature measured by the temperature probe attached to the OsmoSampler. This difference is likely the result of the depth of penetration into the crack and the diffuse nature of flow from the crack that could have been altered when the probe was deployed. Given the similar temperature measurements, the OsmoSampler intake was well located.

An OsmoSampler and temperature probe were deployed for 351 days at Naha. The temperature probe recorded data throughout the deployment; however, the OsmoSampler failed after $\sim 3$ months. This failure was caused by precipitates that clogged the sample tubing within the first few centimeters of the sample intake in the $T$ handle. When the precipitates became dense enough to generate sufficient resistance to flow, seawater was pulled into the distilled water reservoir at the junction between this reservoir and the sample tubing (Figure 2). Thus bottom seawater was collected and homogenized in the distilled water reservoir for the remainder of the year. Given the volume of this reservoir, the chlorinity of the fluid in the reservoir (note that $\mathrm{Cl}$ cannot pass through the membrane and the chlorinity of this fluid was too low to have a significant effect on the rate of pumping), the amount of hydrothermal fluid in the sample coil, deployment and recovery dates, and a constant pump rate that is mandated by the lack of variation in temperature at the pump. This OsmoSampler collected fluids in the sample coil for 87 days before the failure occurred.

The failure was caused by the precipitation of iron oxide sheaths that are biological in origin. The microbial species responsible for these sheaths have been cultured and tentatively identified as iron-oxidizing bacteria, similar to those previously described by Emerson and Moyer [1997]. These iron-oxidizing bacteria are commonly found on Loihi Seamount and have had their relative abundance and phylogeny assessed [Moyer et al., 1994, 1995]. In the sample tubing these bacteria were responsible for removing $\mathrm{Fe}$ from the vent fluids, resulting in measured concentrations $<0.1 \mu \mathrm{mol} \mathrm{Fe} / \mathrm{kg}$. These precipitates would likely strip the hydrothermal fluid of $\mathrm{P}, \mathrm{V}, \mathrm{Cr}, \mathrm{U}$, and other elements that have an affinity for $\mathrm{Fe}-$ oxide surfaces, but analyses were not conducted for these elements. We show below that $\mathrm{Mn}$ and the other elements that were measured were not affected by this precipitation.

A second OsmoSampler with a temperature probe was deployed at Lohiau in a vent that exited through a talus pile on a $45^{\circ}$ slope. This talus contained sulfates and sulfides [Davis and Clague, 1998] and was located less than a meter from an outcrop that extended $2 \mathrm{~m}$ above the talus slope. The outcrop provided a secure site for the sampler yet allowed us to position the sample intake in a site where temperatures reached $53^{\circ} \mathrm{C}$, based on measurements with the probe attached to the submersible. We excavated this site to secure the intake and covered the site with additional rocks to diminish the effects of dilution with bottom seawater. The temperature probe on the OsmoSampler measured an initial temperature of $27^{\circ} \mathrm{C}$, indicating that there was significant dilution of the effluent at the intake of the OsmoSampler.

The sampler at Lohiau also became clogged with bacterial sheaths within centimeters of the sample intake. Resistance to flow from these sheaths caused a failure, allowing seawater to enter through a weak portion of the 200 -m-long sample tubing. This break in the tubing occurred $\sim 90 \mathrm{~m}$ from the junction between the distilled water reservoir and sample tubing. Using the arguments that were presented above, the failure occurred on the fifth day, resulting in a $1-\mathrm{m}$ separation between the temperature probe and the "new" fluid intake. Immediately after the failure the OsmoSampler collected mostly bottom seawater through the new intake. However, during the deployment an iron oxide-nontronite blanket formed over the pump and sample tubing. Hydrothermal fluids flowed below this blanket, thereby creating a reduced, anoxic environment around the sampler. This combination of the blanket and the break in the sample tubing provide us with a record of the composition of vent fluids under the blanket for the last 47 days of the 336-day deployment without complications from bacterial processes (e.g., formation of Fe-oxide sheaths). Samples from the preceding 276 days were lost because they were pumped through the sample tubing and into the distilled water reservoir where they were homogenized.

\subsection{Data From Naha and Pohaku}

The temperature record from Naha shows an increase from $20^{\circ} \mathrm{C}$ to $21^{\circ} \mathrm{C}$ within the first month of the deployment, after which the temperature slowly decreased with time (Figures 3 


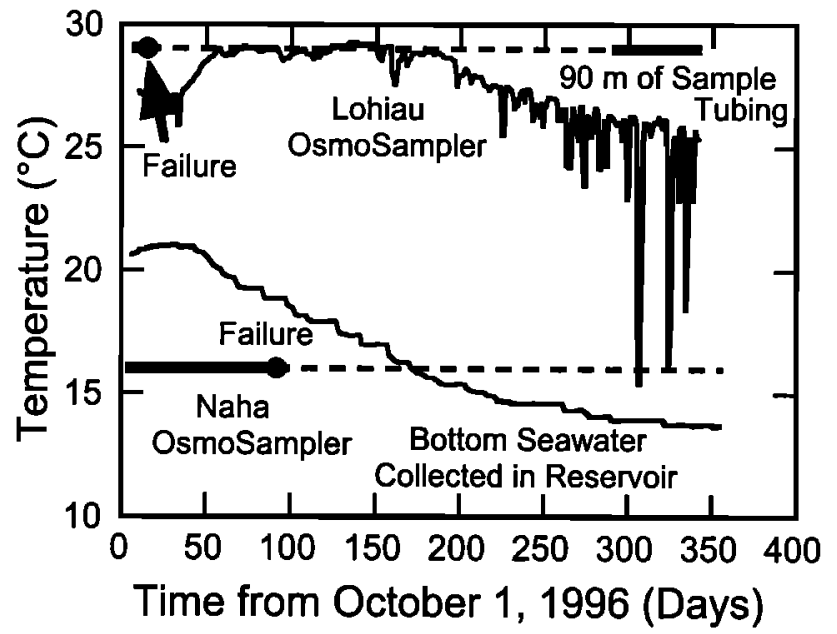

Figure 3. Temperature record for the probes deployed with the OsmoSamplers at Naha and Lohiau. Superimposed on this plot are time lines that illustrate when samples were collected in the sample tubing (heavy lines), when failures occurred (dots), and when fluids were collected but homogenized in the distilled water reservoir (dashed lines).

and 4). This decrease occurred as a series of step functions resulting in a stair-step appearance with time. The largest of these decreases in temperature was -0.4 to $1.0^{\circ} \mathrm{C}$, and the temperature at the time of recovery was $13.7^{\circ} \mathrm{C}, \sim 10^{\circ} \mathrm{C}$ above ambient. Temperature fluctuations were no greater than $0.2^{\circ} \mathrm{C}$ throughout the deployment.

An example of representative thermal and chemical changes that occurred during the first 87 days of the OsmoSampler deployment at Naha are shown in Figure 4. For example, in the first 30 days the chlorinity increased from a concentration that was $3 \mathrm{mmol} / \mathrm{kg}$ below that of bottom seawater (538.6 $0.5 \mathrm{mmol} / \mathrm{kg}$ ) to one that was $2 \mathrm{mmol} / \mathrm{kg}$ above the concentration in bottom seawater (Figures 4 and 5). We also show concentrations of $\mathrm{Mn}$ and $\mathrm{Si}$ that decrease almost monotonically during the first 55 to 65 days, after which concentrations remained uniform (Figure 4). These decreases in concentration accompany a decrease in temperature with time. The ratio of the chemical to thermal anomaly also decreases with time (Figure 4).

To illustrate the good quality of these data and the lack of storage problems, we plot concentrations of both discrete and continuous data for various chemical species against a measure of the extent of dilution of a source fluid with bottom seawater. Here we use concentrations of dissolved silica as this measure. Mg is typically used in this context because it is depleted and nonreactive in the upwelling portion of typical hydrothermal systems on mid-ocean ridges. $\mathrm{Mg}$ was not used here because (1) concentrations of $\mathrm{Mg}$ generally remain within $\pm 1 \%$ of the concentration in bottom seawater, in contrast to concentrations of Si which are elevated more than 16 times the concentration in bottom seawater and (2) concentrations of $\mathrm{Mg}$ at Naha in 1996 are even greater than that in bottom seawater, implying that there is a source of $\mathrm{Mg}$ to these fluids (Figure 5).

Hydrothermal fluids from Loihi Seamount before the 1996 event had anomalously high alkalinities [Sedwick et al., 1992]. Alkalinities were even higher in vent fluids from Naha and Pohaku after the event (maximum of $10.1 \mathrm{mmol} / \mathrm{kg}$, Figure 6). Alkalinities at Naha decreased during the deployment of the
OsmoSampler, but samples collected in 1997 still had higher alkalinities than those collected before the event. In contrast, concentrations of $\mathrm{Ca}$ immediately following the event increased during the first 49 days of the deployment. The last 37 days of the continuous $\mathrm{Ca}$ record lie on the mixing line based on discrete samples that were collected during the September 1997 operations. More extreme changes in alkalinity and $\mathrm{Ca}$ for a given concentration of $\mathrm{Si}$ were observed at Pohaku. Within analytical uncertainty, concentrations of $\mathrm{Sr}$ did not change during the year at either site.

An inverse relationship was observed between concentrations of sulfate and $\mathrm{Ba}$ at $\mathrm{Naha}$ (Figure 6). Concentrations of sulfate in fluids from the OsmoSampler increased during the first 55 to 65 days of operation to concentrations above that in bottom seawater $(27.8 \mathrm{mmol} / \mathrm{kg})$. During this period concentrations of $\mathrm{Ba}$ decreased in these fluids. Molar ratios of sulfate/Si and $\mathrm{Ba} / \mathrm{Si}$ in discrete samples from 1996 were lower at Pohaku than at Naha. In contrast to the data from Naha, molar ratios of sulfate/Si and $\mathrm{Ba} / \mathrm{Si}$ increased slightly from 1996 to 1997 at Pohaku.

The chemical evolution of fluids from these two sites is different. For example, the $1996 \mathrm{~K}$ data from both sites and the $1997 \mathrm{~K}$ data from Pohaku lie along the same mixing line with respect to silica, a line with a positive slope pointing toward an end-member fluid with a concentration of $\mathrm{K}$ greater

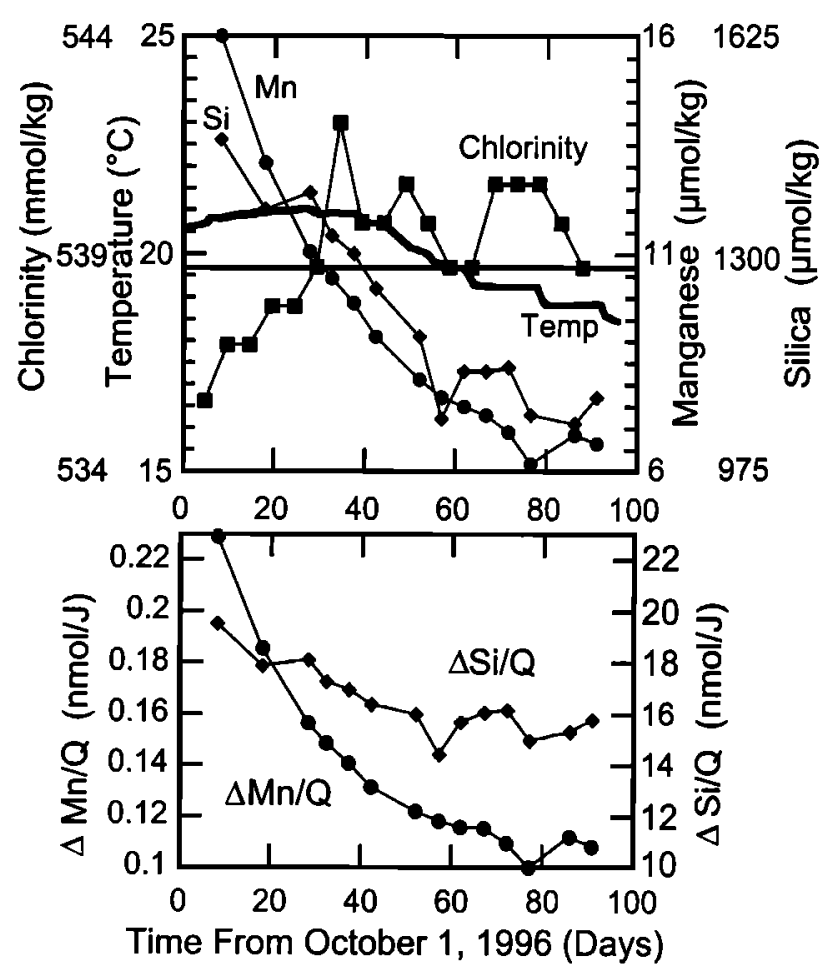

Figure 4. Temporal changes in temperature and selected chemical (chlorinity, $\mathrm{Si}, \mathrm{Mn}$ ) data from the OsmoSampler at Naha. The chlorinity of bottom seawater $(538.6 \mathrm{mmol} / \mathrm{kg})$ is represented by a horizontal line. Chlorinity in fluids collected with the OsmoSampler increase during the first 30 days of the deployment. An almost monotonic decrease in the concentrations of $\mathrm{Si}$ and $\mathrm{Mn}$ was observed during the first 55 to 65 days of the deployment. These chemical trends in concert with a decrease in the ratios of $\mathrm{Si} /$ thermal and $\mathrm{Mn}$ /thermal anomalies with time are consistent with a change in the source fluid composition. 

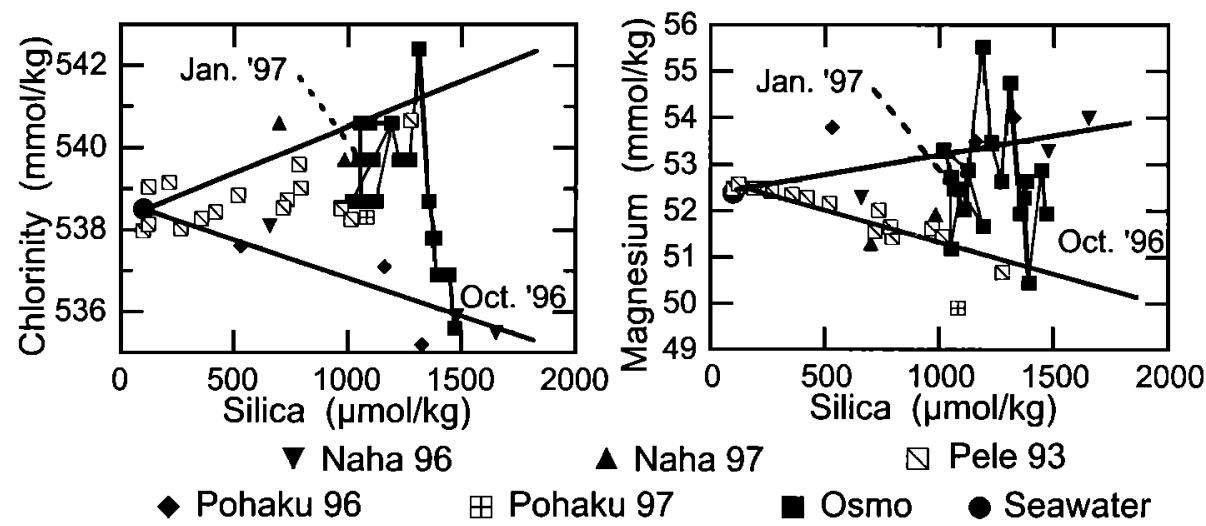

Figure 5. Plots of chlorinity and $\mathrm{Mg}$ versus $\mathrm{Si}$ for fluid samples collected with discrete and continuous samplers at Naha and with discrete samplers at Pohaku and Pele's Vents. Mixing (thick) lines are defined by concentrations of bottom seawater and hydrothermal effluent from discrete samples collected in 1996 and 1997 at Naha. Two mixing lines confirm a change in the fluid composition between submersible operations. Thin lines map the incremental changes in the concentration of samples collected with the OsmoSampler. Dates represent time stamps for the data from the OsmoSampler with the lowest concentrations of $\mathrm{Si}$ at the end of the record. Note that concentrations of $\mathrm{Mg}$ in many of these samples are greater than the measured concentration in bottom seawater $(52.4 \mathrm{mmol} / \mathrm{kg})$. Data from Pele's Vents before the 1996 event are included for comparison.

than that in bottom seawater (Figure 6). In contrast, concentrations of $\mathrm{K}$ at Naha decreased below this line and below the concentration in bottom seawater. This change occurred during the first 10 days after the deployment of the OsmoSampler and continued throughout the deployment. The last few samples from the 87-day record, however, lie along the mixing line defined by discrete samples collected in 1997.

Molar ratios of $\mathrm{Mn} / \mathrm{Si}$ decreased with time at both sites (Figure 6). Data from the initial samples collected with the OsmoSampler match those from discrete samples, suggesting that no $\mathrm{Mn}$ was removed by inorganic or bacterial oxidation processes or by particle adsorption in the sample tubing. The lack of bacterial removal of $\mathrm{Mn}$ from these fluids is consistent with the lack of specific Mn-oxidizing bacteria. Several unsuccessful attempts have been made to enrich for and isolate Mn-oxidizing bacteria from Loihi Seamount (C. Moyer, unpublished data, 1999).

The good quality of the data from the OsmoSampler at Naha is evident from the fit of these data at the beginning of the deployment to mixing lines defined by bottom seawater and hydrothermal samples collected using discrete samplers in 1996.

\subsection{Data From Lohiau}

Temperature data from Lohiau show a general increase from 27.1 to $29.2^{\circ} \mathrm{C}$ in the first 6 weeks followed by a 15 -week period of relatively uniform temperatures before decreasing gradually to $26.0^{\circ} \mathrm{C}$ at the end of the 336-day record (Figure 3). A few sporadic drops in temperature of $\sim 2^{\circ} \mathrm{C}$ were observed during the first 7 months of the deployment. More frequent and larger drops in temperature $\left(3-12^{\circ} \mathrm{C}\right)$ occurred during the last 18 weeks of the deployment. These temperature excursions lasted for as long as 1 to 2 days.

The 47-day record of chlorinity, temperature, $\mathrm{Ca}$, and $\mathrm{Fe}$ from Lohiau obtained at the end of the deployment illustrates the "typical" trends observed in the other ions (Figure 7).
There is a change from a more hydrothermally altered fluid to a less altered fluid then back to a more altered fluid that is independent of perturbations in temperature recorded at the vent. This lack of dependence is not surprising given that the sample intake and temperature probe were separated by $\sim 1 \mathrm{~m}$ throughout most of the operation.

To illustrate changes in the composition at this site, we plot dissolved ions versus $\mathrm{Mg}$. $\mathrm{Mg}$ is used here as the measure for the dilution of a source fluid with bottom seawater even though there is evidence for the addition of $\mathrm{Mg}$ to the hydrothermal fluid as this fluid ascends within the crust. $\mathrm{Mg}$ was chosen because the $\mathrm{Mg}$ anomaly is sufficiently large relative to the analytical precision, and concentrations of dissolved silica were likely affected by precipitation reactions underneath the Fe-oxide-nontronite blanket before these fluids were collected in the sample tubing. Precipitation is surmised because all of the silica data from the OsmoSampler are centered $\sim 2 \mathrm{mmol} / \mathrm{kg}$ (Figure 8). This concentration is well below the concentration expected based on discrete samples and is about the expected value for equilibrium with amorphous silica at $25^{\circ} \mathrm{C}$ [Walther and Helgeson, 1977]. The alternative hypothesis is that $\mathrm{Si}$ precipitated in the sample tubing. This hypothesis is unlikely, given that the most recent samples from Lohiau were only days old when the sampler was recovered and concentrations of $\mathrm{Si}$ during a 5-day deployment of an OsmoSampler on Axial Seamount maintained the in situ concentration of $16.5 \mathrm{mmol} \mathrm{Si} / \mathrm{kg}$ (data are not shown).

Only three discrete samples were collect from Lohiau in 1997. Each of these samples was collected from the location where the $\mathrm{T}$ handle was deployed. These three samples commonly plot along the same mixing line that was determined by samples from 1996, most of which were from this same location (e.g., chlorinity; Figure 8). A comparison between the discrete data and data from the OsmoSampler illustrate that the OsmoSampler collected fluids from a different source. For example, the chlorinity data from the last 

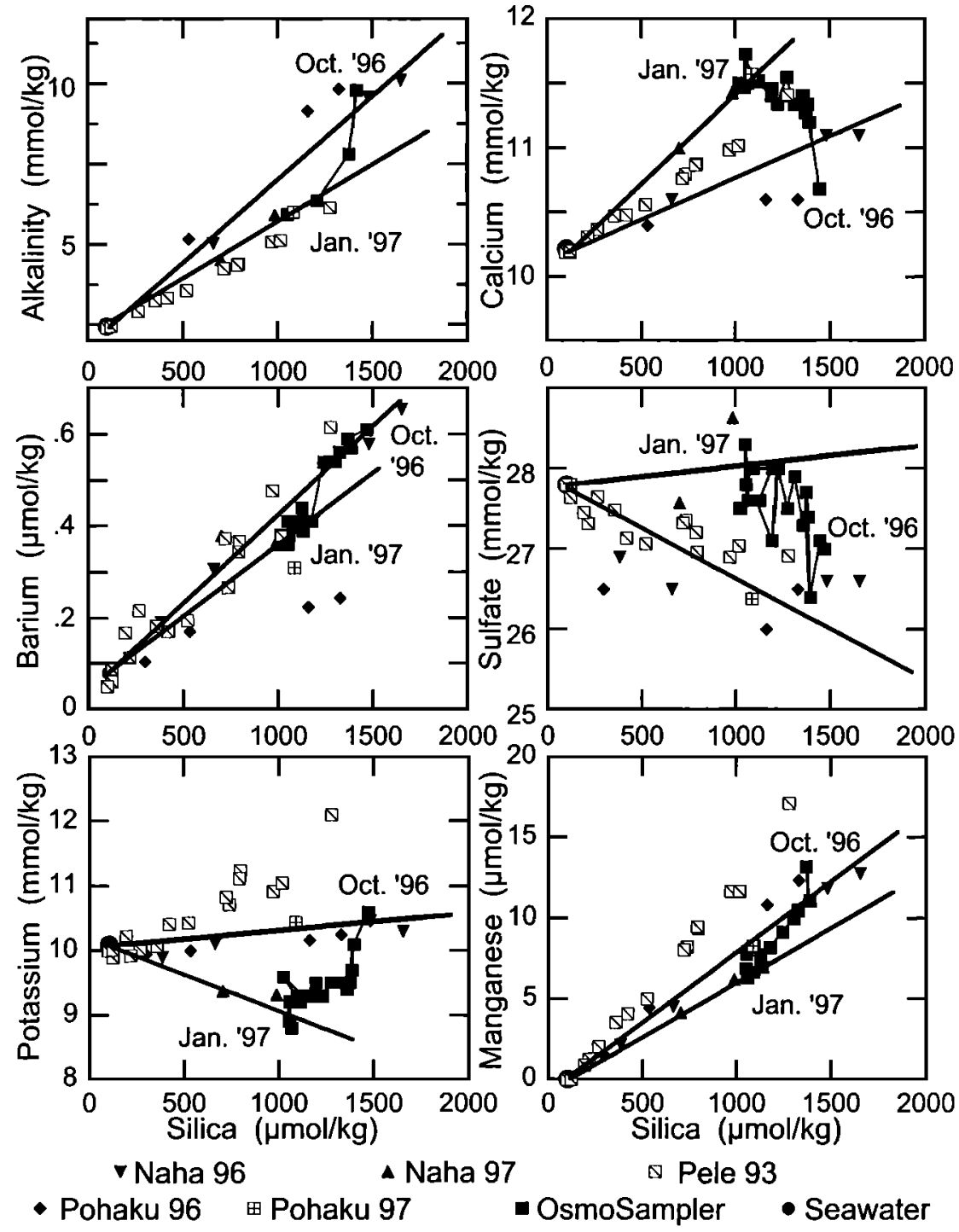

Figure 6. Plots of concentrations of dissolved chemical species (alkalinity, Ca, Ba, sulfate, $\mathrm{K}$, and $\mathrm{Mn}$ ) versus $\mathrm{Si}$ for samples from Naha and Pohaku. As in Figure 4, we included mixing lines (thick lines) for discrete samples from Naha, the incremental change (thin line) in concentration recorded by the OsmoSampler at Naha, dates that correspond to samples collected by the OsmoSampler, and data from Pele's Vents before the 1996 event. Two mixing lines confirm a change in the fluid composition between submersible operations. Most of the data from the OsmoSampler are bounded by theses two mixing lines. Data from the beginning of the OsmoSampler record match data from discrete samples collected in 1996 and data from the end of the OsmoSampler record match data from discrete samples collected in 1997.

47 days of the deployment are higher for a given concentration of $\mathrm{Mg}$ than any of the discrete vent fluids that were collected and the few samples from the first 5 days of the deployment. This distinction between samples from the OsmoSamplers and discrete samplers is not as evident in the other chemical data, with the possible exception of the sulfate and Ba data (Figure 9). This result is not surprising, given that the break in the sample tubing resulted in a $1-\mathrm{m}$ separation between the new sample intake and the $\mathrm{T}$ handle and the porous talus cover likely allows for various degrees of subsurface mixing with bottom seawater and hydrothermal fluids.

Data for other chemical species also are consistent with the presence of a variety of chemically different fluids that vent from this hydrothermal site. For example, three discrete hydrothermal samples from an orifice that was located $\sim 5 \mathrm{~m}$ from the location where the OsmoSampler was deployed have a lower alkalinity for a given change in $\mathrm{Mg}$ relative to samples from the orifice where OsmoSampler was deployed (Figure 9). Similarly, a plot of $\mathrm{Fe}$ versus $\mathrm{Mn}$ reveal that these three discrete samples are distinct from the other discrete samples collected at this site (Figure 10). Data from the OsmoSampler reside between the mixing lines defined by the data from these two orifices (Figures 9 and 11). In contrast to the alkalinity and $\mathrm{Fe}$ data, two distinct mixing trends are not observed in $\mathrm{Ca}$, $\mathrm{Ba}$, sulfate, $\mathrm{K}$, and $\mathrm{Mn}$ data from discrete samples collected in 1996 (Figure 9). Trends of Sr versus $\mathrm{Mg}$ are similar to the $\mathrm{Ca}$ versus $\mathrm{Mg}$ trends and are not shown.

The inverse relationship between sulfate and $\mathrm{Ba}$ that was observed at Naha also was observed at Lohiau. Relative to discrete samples, higher concentrations of sulfate in samples 


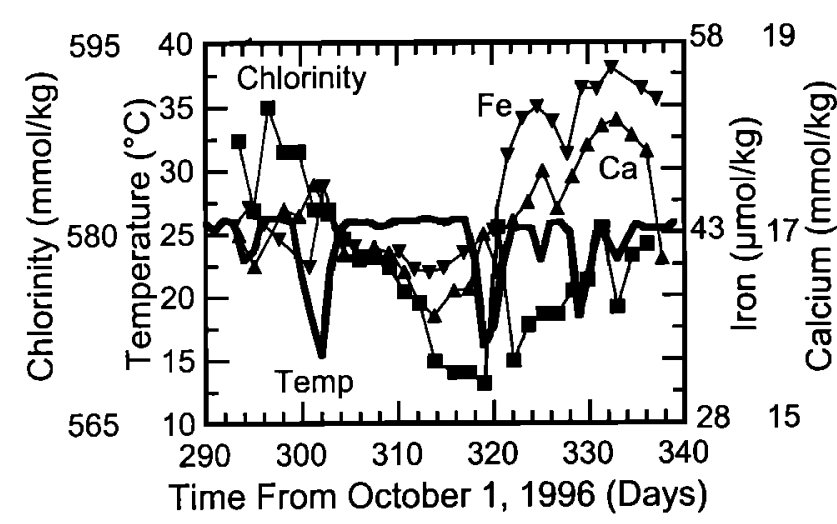

Figure 7. Temporal changes in temperature and selected chemical (chlorinity, Fe, Ca) data from the OsmoSampler at Lohiau. Chemical data map one another, illustrating that OsmoSamplers can be used to monitor redox-sensitive dissolved metals. Chlorinity and temperature scales are different from those in Figure 4.

from the OsmoSampler coincide with lower concentrations of $\mathrm{Ba}$ (Figure 9). Sulfate and Ba data from the first 5 days of operations at Lohiau imply that we altered the system when we excavated to deploy the sample intake. In contrast, $\mathrm{K}$ and $\mathrm{Mn}$ data from the OsmoSampler both before and after the failure generally fall along the trend defined by the discrete samples. The good quality of the data, including the Fe data (Figure 11), from the OsmoSampler at Lohiau is evident from the fit of these data from near the end of the deployment to a mixing line defined by samples collected using discrete samplers in 1997.

\section{Discussion}

The data presented above illustrate that OsmoSamplers are useful for monitoring temporal changes in the composition of hydrothermal vent fluids. In this section we discuss the waterrock and thermal conditions at depth that impart a signature upon hydrothermal discharge. We then present evidence that the hydrothermal system on Loihi is cooling and compare our results with a model for the evolution of hydrothermal systems after an event. Finally, we present concerns for estimating oceanic geochemical fluxes from hydrothermal systems altered by magmatic-tectonic events.

\subsection{Implications of Observed Chemical Changes}

The sampler at Naha captured a fundamental change in the chemical composition of the venting fluid from a fluid with a lower chlorinity than bottom seawater to one with a higher chlorinity. This change occurred during the first 30 days of the deployment. The low chlorinities could reflect (1) the addition of magmatic water, from either a slightly evolved chamber gas generated by a parental magma (type 1 [Gerlach and Greaber, 1985]) or from the complete crystallization of a dike [Shanks et al., 1995]; (2) phase separation followed by phase segregation [Massoth et al., 1989; Butterfield et al., 1990; Von Damm et al., 1995]; and/or (3) the precipitation of Cl-bearing minerals [Seyfried et al., 1986]. A temperature above $\sim 330^{\circ} \mathrm{C}$, which is the boiling temperature at the depth of Naha [Bischoff and Rosenbauer, 1988], is required for any of these processes to occur. Higher temperatures in excess of $375^{\circ} \mathrm{C}$ are required if phase separation occurred at a depth of $1 \mathrm{~km}$ below the vents. A slightly higher temperature is required to generate $\mathrm{Cl}$-rich phases [Seyfried et al., 1986], and an even higher temperature is associated with the release of magmatic water near the source of this water.

The low chlorinity of Naha and Pohaku fluids from 1996 thus requires a high-temperature component, but there is evidence suggesting that these fluids also have a low-temperature component. Concentrations of $\mathrm{K}$ in Naha fluids were 0.5 $\mathrm{mmol} / \mathrm{kg}$ above that of bottom seawater $(10.1 \mathrm{mmol} / \mathrm{kg})$ during submersible operations in 1996 and in the first sample collected with the OsmoSampler. Ten days after the OsmoSampler was deployed, however, the concentration of $\mathrm{K}$ decreased below the concentration in bottom seawater and continued to decrease during the first 2 months of the deployment, even though chemical weathering in acidic $\mathrm{CO}_{2}$-rich environments should enhance the extraction of $\mathrm{K}$ from the

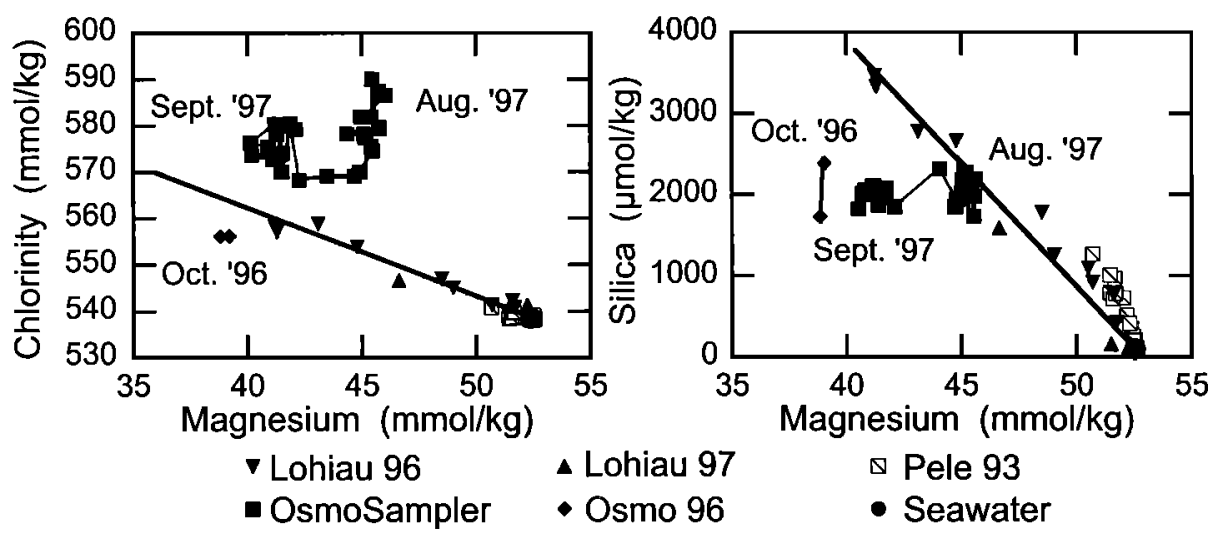

Figure 8. Plots of chlorinity and Si versus $\mathrm{Mg}$ for samples collected with discrete and continuous samplers at Lohiau and with discrete samplers at Pele's Vents. A single mixing (thick) line is defined by concentrations of bottom seawater and hydrothermal effluent from discrete samples, suggesting that the chemical composition of the source fluid during submersible operations is the same even though samples were collected $\sim 1$ year apart. Thin lines map the incremental changes in the concentration of samples collected with the OsmoSampler. Dates represent time stamps for the data from the OsmoSampler. Osmo ‘ 96 refers to the few samples that were collect during the first few days of the deployment before the failure. Data from Pele's Vents before the 1996 event are included for comparison. 

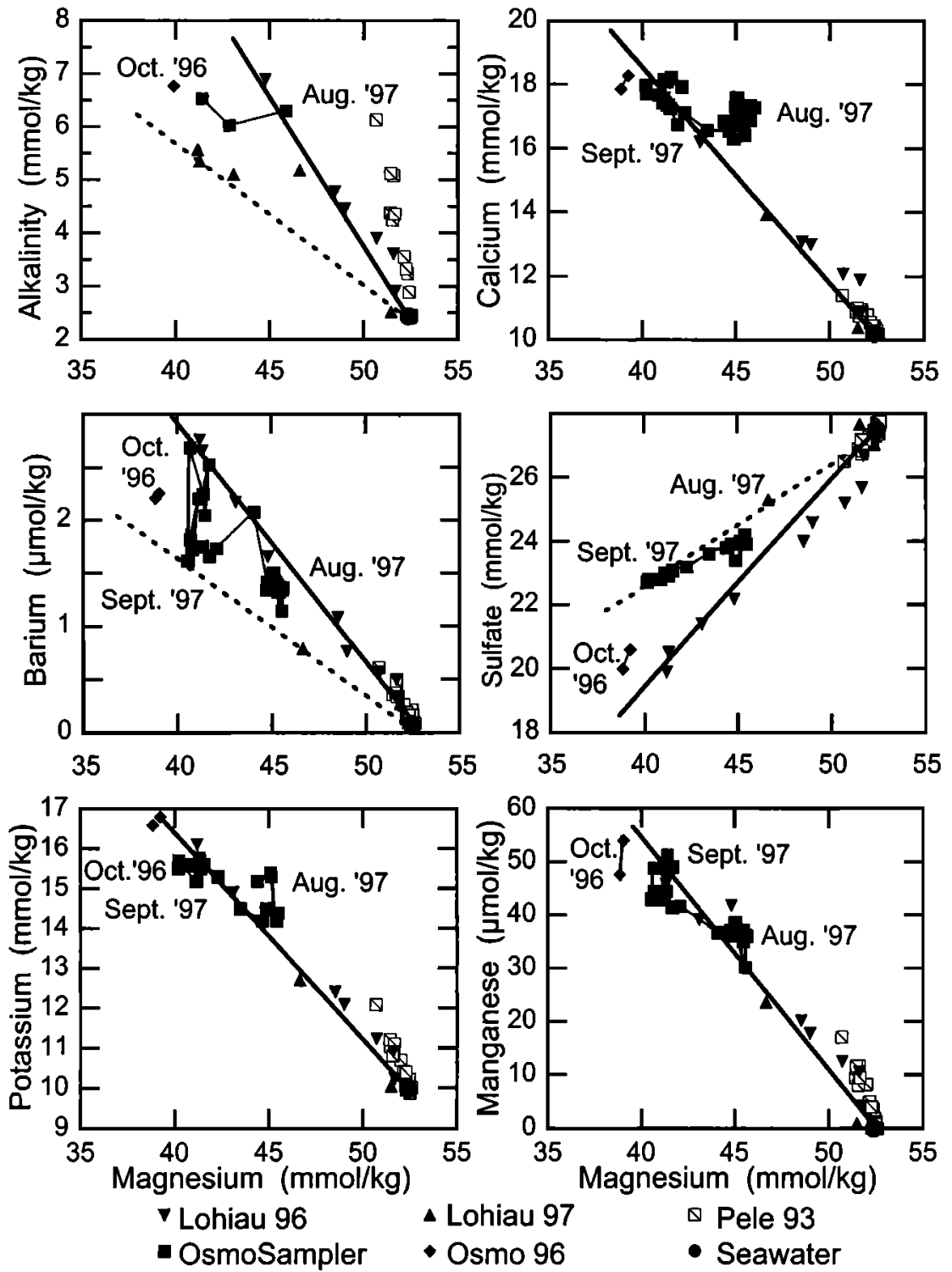

Figure 9. Concentrations of dissolved chemical species (Alkalinity, $\mathrm{Ca}, \mathrm{Ba}$, sulfate, $\mathrm{K}$, and $\mathrm{Mn}$ ) versus $\mathrm{Mg}$. As in Figure 8, mixing lines (thick lines) and the incremental change (thin lines) in concentration recorded by the OsmoSampler at Lohiau are shown. A second mixing line (dashed line) for the alkalinity plot is defined by three discrete samples collected from an orifice that was $\sim 5 \mathrm{~m}$ from where the OsmoSampler was deployed. Additional mixing lines (dashed lines) for $\mathrm{Ba}$ and sulfate are based on one sample collected during 1997. Dates correspond to samples collected by the OsmoSampler and allow for estimating time-dependent trends. Different symbols (diamonds, Osmo '96) are used for the samples collected during the first few days of the deployment before the failure. Data from Pele's Vents before the 1996 event are included for comparison.

crust [Mackenzie and Garrels, 1966]. One possibility for the observed change in composition is a decreasing contribution from a vapor component. There is a near-constant $\mathrm{K} / \mathrm{Cl}$ molar ratio $(\sim 0.043)$ of vapor-dominated hydrothermal fluids from Axial Volcano [Butterfield et al., 1990], which is a hot spot volcano with hydrothermal fluids that are rich in $\mathrm{CO}_{2}$ and vent at depths similar to those found on Loihi. The $\mathrm{K} / \mathrm{Cl}$ molar ratio in Naha fluids, however, is not constant and thus is inconsistent with a simple temporal decrease in the flux of a vapor component. An alternative and more likely hypothesis is that the low concentrations of $\mathrm{K}$ result from the influence of a low-temperature component. Hydrothermal fluids that react with basalt are enriched with $\mathrm{K}$ given reaction temperatures in excess of $150^{\circ} \mathrm{C}$ [Seyfried and Bishoff, 1979]. At lower temperatures, $\mathrm{K}$ is removed from circulating seawater in basaltic basement [e.g., Seyfried and Mottl, 1982; Alt et al., 1996; Elderfield et al., 1999; Wheat and Mottl, 2000]. In conclusion, given the two K-Si mixing lines and changes in the $\mathrm{Mn} /$ thermal and $\mathrm{Si}$ /thermal anomalies, fluids from Naha have two or more distinct sources, one generated by reaction of seawater with basalt at low temperatures and at least one that includes volatile gases that are magmatic in origin [Sedwick et al., 1994; Sansone et al., 1994, 1998].

The OsmoSampler at Lohiau recovered fluids with an $\mathrm{Fe} / \mathrm{Mn}$ molar ratio of $\sim 6$, the value determined from discrete samples collected both during deployment and recovery 


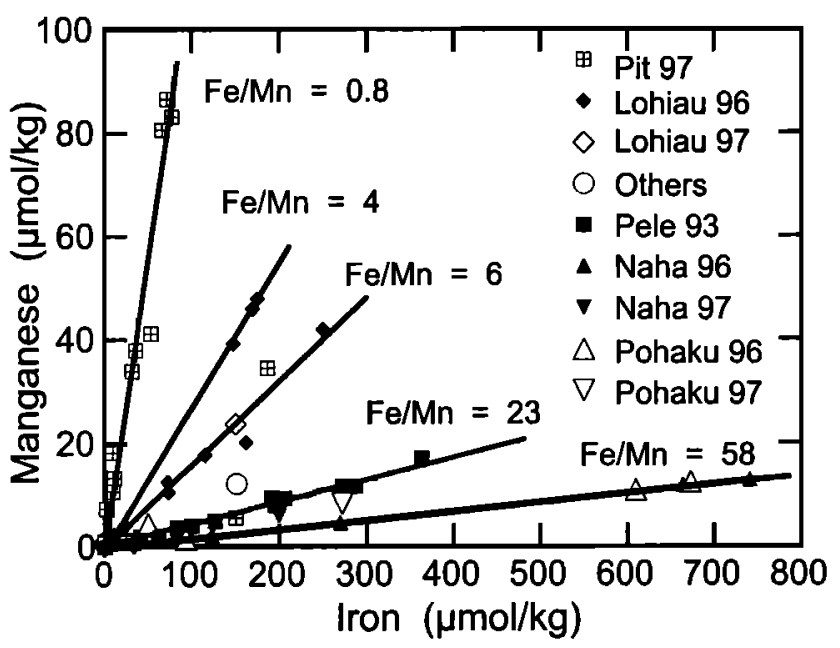

Figure 10. Mn versus Fe for all of the discrete vent samples collected in 1993 through 1997. The range in the Fe/Mn molar ratio is the largest measured to date. Fluid samples with higher molar ratios have higher alkalinities, implying that the weathering of basaltic crust at depth is enhanced by inputs of magmatic volatiles. Note that there are two Fe/Mn molar ratios for fluids from Lohiau in 1996. Fluids with Fe/Mn equal to 6 are from the orifice where the OsmoSampler was deployed. The three samples from Lohiau with $\mathrm{Fe} / \mathrm{Mn}$ equal to 4 were collected from an orifice $\sim 5 \mathrm{~m}$ from where the OsmoSampler was deployed. These fluids also have lower alkalinities for a given $\mathrm{Mg}$ anomaly (dashed line in the alkalinity versus $\mathrm{Mg}$ plot in Figure 9).

(Figure 10). This ratio is significantly lower than the ratio of $\sim 23$, which was the measured ratio before the event. $\mathrm{Fe} / \mathrm{Mn}$ ratios in vent fluids from Loihi range from 58 in fluids from Naha and Pohaku to 0.8 in fluids from Pele's Pit (Figure 10). Low $\mathrm{Fe} / \mathrm{Mn}$ ratios measured in fluids from Pele's Pit likely result from high temperature rock-dominated, water-rock reactions similar to those reproduced in laboratory experiments [Seyfried and Mottl, 1982] and measured during chronic high-temperature venting on mid-ocean ridges ( 0.05 to 3.8 [Massoth et al., 1989, 1995, 1998; Butterfield et al., 1990; Butterfield and Massoth, 1994]). These low values may in part result from the subsurface removal of $\mathrm{Fe}$ by precipitation with sulfide. Subsurface precipitation at Loihi is consistent with the low concentrations of hydrogen sulfide $\quad<11$ $\mu \mathrm{mol} / \mathrm{kg}$ ) in all of the vent fluids collected to date. In contrast to samples from Pele's Pit, samples from Naha and Pohaku have a $\mathrm{Fe} / \mathrm{Mn}$ ratio of 58 , which is about that measured in whole rock samples from Loihi ( 54 [Frey and Clague, 1983]).

The $\mathrm{Fe} / \mathrm{Mn}$ molar ratio increases with alkalinity. For example, fluids from Naha and Pohaku have alkalinities that are $>10 \mathrm{mmol} / \mathrm{kg}$, almost twice the highest value measured before the event. Even high-temperature $\left(200^{\circ} \mathrm{C}\right)$ fluids from Pele's Pit have higher alkalinities than that in bottom seawater but are much lower than concentrations in fluids before the event. In contrast, typical high-temperature hydrothermal systems have alkalinities that are less than the value in bottom seawater and often negative. An additional correlation between the $\mathrm{Fe} / \mathrm{Mn}$ ratio and alkalinity is the observed decrease in the $\mathrm{Fe} / \mathrm{Mn}$ ratio of vent fluids from Naha and Pohaku (Figure 10) that coincides with a decrease in alkalinity for a given concentration of $\mathrm{Si}$ (Figure 6). Given that the $\mathrm{pH}$ of fluids from discrete samples is 5.2 in 1996 and 1997, the measured decrease in alkalinity likely corresponds to a decrease in the extent of magmatic inputs of $\mathrm{CO}_{2}$. Similarly, samples from Lohiau with a low Fe/Mn ratio (Figure 10) also have a lower alkalinity for a given concentration of $\mathrm{Mg}$ (Figure 9). On the basis of this correlation of the $\mathrm{Fe} / \mathrm{Mn}$ ratio and alkalinity, we suggest that the $\mathrm{CO}_{2}$ content and the subsequent weathering of basalt that produces acidity controls the $\mathrm{Fe} / \mathrm{Mn}$ ratio in hydrothermal fluids at Loihi and not the water-rock ratio or complexation with chloride [Ding and Seyfried, 1992; Seyfried and Mottl, 1992]. The role of residence time is unclear; however, a longer residence time affords more complete weathering reactions and possibly a higher $\mathrm{Fe} / \mathrm{Mn}$ ratio. The role of temperature may also be important, because experimental evidence indicates that the reactivity of $\mathrm{CO}_{2}$ with rhyolite is at its maximum between $150^{\circ}$ and $200^{\circ} \mathrm{C}$ and relatively unreactive at temperatures $>270^{\circ} \mathrm{C}$ [Bischoff and
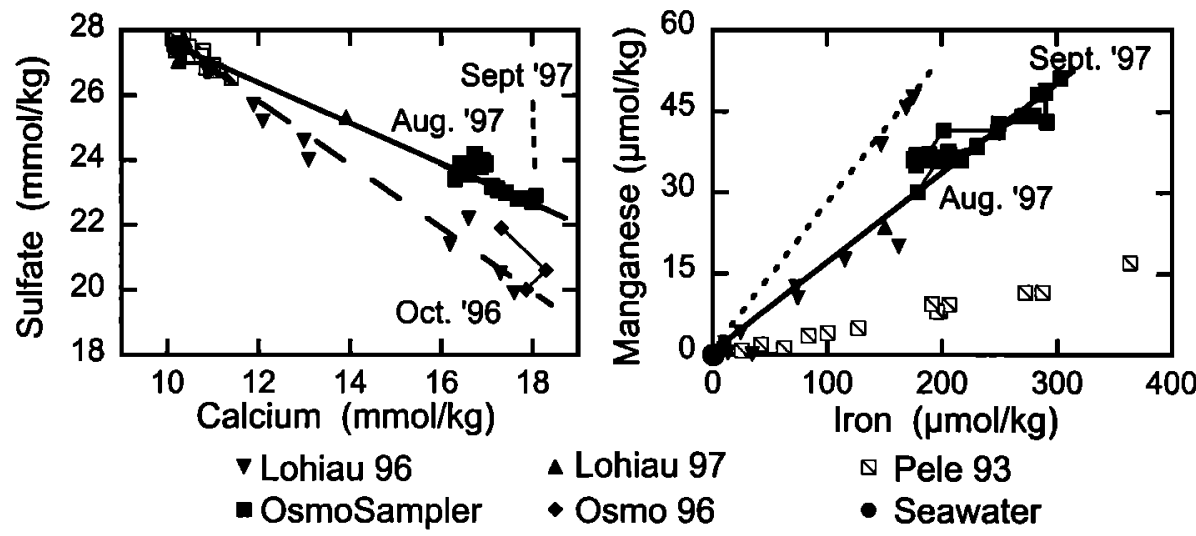

Figure 11. Plots of concentrations of dissolved chemical species (sulfate versus $\mathrm{Ca}$ and $\mathrm{Mn}$ versus $\mathrm{Fe}$ ) at Lohiau. Mixing (thick) lines are defined by concentrations of bottom seawater and hydrothermal effluent from the last month of the deployment of the OsmoSampler. Dates correspond to samples collected by the OsmoSampler. Samples that fit this mixing line reflect various degrees of mixing of a common source with bottom seawater. Additional mixing lines (Dashed) are included. The two mixing lines in the sulfate versus Ca plot are consistent with a change in plumbing between submersible operations. The two mixing lines in the $\mathrm{Mn}$ versus Fe plot illustrate that fluids with different compositions vent near one another. Data from Pele's Vents before the 1996 event are include for comparison. 
Rosenbauer, 1996]. In conclusion one might expect a correlation between the Fe/Mn ratio and the flux of magmatic $\mathrm{CO}_{2}$ into a hydrothermal system. If we expand upon this suggestion and consider that hydrothermal plumes generated from events have a $\mathrm{Fe} / \mathrm{Mn}$ ratio of $7 \pm 3$ based on data from eight plumes that have been sampled to date [Massoth et al., 1998], higher $\mathrm{Fe} / \mathrm{Mn}$ ratios in event plumes may in part result from the enhanced weathering of basaltic crust due to the production of acid from inputs of $\mathrm{CO}_{2}$ or from other acid-producing weathering reactions [Resing and Sansone, 1999].

\subsection{Implications of Observed Thermal Changes}

Temperature data from Naha show an overall decrease throughout the year (Figure 3). This decrease could be caused by (1) slower flow and conductive cooling, which results in an increase in the chemical to thermal anomaly; (2) greater mixing with bottom seawater, which retains the initial chemical to thermal anomaly; or (3) changes in the source fluid. During the initial 87-day period at Naha, ratios of chemical to thermal anomalies decreased and chemical molar ratios changed consistent with changes in the composition of the source fluid (Figure 4 and 6). At the end of this 87-day period the composition of hydrothermal fluid from the last sample collected by the OsmoSampler (January 1997) matched the composition of the most Si-rich discrete sample collected in September 1997 (Figure 6). During this period the hydrothermal temperature decreased from $18.5^{\circ} \mathrm{C}$ to $13.5^{\circ} \mathrm{C}$ (background temperature of $\sim 4^{\circ} \mathrm{C}$ ). The constant composition and decrease in temperature during this period result in an increase in the chemical to thermal anomaly consistent with the loss of heat from conduction during ascent. This result illustrates that the thermal and chemical transport mechanisms are decoupled. Visual observations confirmed at least an order of magnitude decrease in the fluid flux between submersible operations. This decrease in fluid flux may have produced the stair-steplike features in the temperature data (Figure 3).

The effluent temperature and fluid flux from Pohaku also decreased between submersible operations in 1996 and 1997. Given the similar geologic setting and composition of vent fluids between this site and Naha, we conclude that the two sites were initially hydrologically similar. Even though the fluid compositions at both sites remain similar in 1997, they have distinctly different concentrations of $\mathrm{K}$. This difference is consistent with a change in the hydrologic regime shortly after the deployment of the OsmoSampler.

The temperature record at Lohiau and visual observations from the submersible are consistent with a decrease in the fluid flux at this site as well. Much of this decrease probably occurred after the seventh month of the deployment when more frequent, larger magnitude, and shorter duration decreases in temperature were recorded (Figure 3). Similar thermal spikes have been documented at other hydrothermal sites [Tivey et al., 1990; Chevaldonne et al., 1991; Schultz et al., 1992; Fornari et al., 1998]. Because the temperature probe at Lohiau was buried beneath talus, it was more susceptible to cooling by and mixing with bottom seawater than the sampler at Naha. In contrast, the temperature probe at Naha recorded relatively smooth and monotonic variations, which are consistent with the lack of influence from mixing caused by variations in bottom currents (Figure 3). The thermal spikes at Lohiau could in part result from changes in the fluid flux, consistent with a single mixing trend for discrete samples (Figure 9). The hydrologic setting, however, is more complex. For example, the $\mathrm{Fe}$ and $\mathrm{Mn}$ data from the OsmoSampler fall on the mixing line defined by discrete samples at the beginning and end of the chemical record, but for 17 days the OsmoSampler collected fluids with a lower Fe/Mn ratio, consistent with the presence of more than one hydrothermal fluid (Figure 11). Similar changes were observed in the $\mathrm{Ca}$ and sulfate data (Figure 11).

\subsection{Evolution of the Hydrothermal System}

During and immediately following the event, heat, volatile gases, and hydrothermal fluids issued from Loihi seamount, principally from Pele's Pit. These reduced fluids rapidly oxidized and precipitated, clouding the summit area. Hydrocasts recovered some fluids that contained several micromoles per kilogram of hydrogen sulfide and a conductivity-temperature-pressure (CTD) package detected low-salinity lenses within the pit. These lenses must have resulted from inputs of a vapor phase and/or magmatic degassing/dewatering. The emission of a vapor phase caused by phase separation and segregation during the event would require temperatures $>330^{\circ} \mathrm{C}$. These high temperatures are likely, given the presence of pyrrhotite, wurtzite, and rare chalcopyrite in the talus at Lohiau [Davis and Clague, 1998]. Venting of this effluent was short lived and ceased before our dive operations, which occurred $<3$ months after the onset of the event. We expect that much of the magmatic $\mathrm{CO}_{2}$ degassed near the summit during this period.

In October 1996, degassing from magmatic inputs was still evident at each of the hydrothermal sites that were sampled [Hilton et al., 1998]. Along the south rift at Naha and Pohaku, hydrothermal effluent included a freshened component. Here the flux of freshened fluids decreased continuously during the first month that the OsmoSampler was deployed at Naha. Continuous changes in the chemical composition and ratios of chemical to thermal anomalies also were evident during the first 2 months of the deployment (e.g., $\mathrm{Mn}$ and $\mathrm{Si}$, Figure 4). During this period the concentration of $\mathrm{K}$ in vented fluids became less than that in bottom seawater, consistent with there being a low-temperature component to this fluid. The composition of these fluids from Naha and their evolution are clearly distinct from those that issue from Lohiau (Table 2), implying that the two hydrothermal systems are hydrologically distinct. The likely source for fluids from Lohiau is a high-temperature $\left(>350^{\circ} \mathrm{C}\right)$ end-member similar to ones that have been sampled along mid-ocean ridges where typical fluids are depleted in $\mathrm{Mg}$ and sulfate, have high concentrations of $\mathrm{K}$ relative to seawater, and have slightly elevated chlorinities [i.e., Von Damm, 1995]. However, fluids from Lohiau have higher concentrations of dissolved magmatic gases than typical midocean ridge hydrothermal fluids. These gases in part aid weathering reactions that result in anomalously high concentrations of sulfate, $\mathrm{Mg}$, and alkalinity in the vented fluids [Sedwick et al., 1992].

Our observations of hydrothermal systems on Loihi after the 1996 event are similar to those described by a model of hydrothermal evolution based on the 1993 event on the CoAxial Segment of the Juan de Fuca Ridge [Butterfield et al., 1997]. The model predicts a decrease in thermal, fluid, and hydrogen sulfide fluxes with time, a short-lived vapor phase, and a gradual decrease in the flux of a brine component. Although the timing of these observations is different, a decrease in thermal and fluid fluxes with time was observed at both Naha and Lohiau. In general, fluxes of hydrogen sulfide have diminished with time. For instance, hydrogen sulfide in samples from the water column was only observed during the 
Table 2. Composition of the Most Altered Hydrothermal Fluid From Representative Vents on Loihi Seamount and Seawater at $1000 \mathrm{mbsl}$

\begin{tabular}{lcccc}
\hline & Seawater & Naha 96 & Naha 97 & Lohiau \\
\hline Alkalinity & 2.44 & 10.1 & 5.9 & 6.9 \\
Calcium & 10.2 & 11.1 & 11.4 & 17.3 \\
Magnesium & 52.4 & 54.0 & 51.4 & 41.2 \\
Sulfate & 27.8 & 26.5 & 28.6 & 19.9 \\
Silica & 0.10 & 1.6 & 1.0 & 3.5 \\
Potassium & 10.0 & 10.3 & 9.3 & 16.1 \\
Chlorinity & 538.5 & 535.5 & 540.5 & 558.8 \\
Fe/Mn & - & 58 & 30 & 6 \\
\hline
\end{tabular}

Units are $\mathrm{mmol} / \mathrm{kg}$ except for $\mathrm{Fe} / \mathrm{Mn}$, which is a molar ratio.

expedition that occurred $\sim 1$ month after the onset of the 1996 event. A short-lived vapor phase also is evident from the lack of low-salinity lenses in Pele's Pit after the initial response cruise and the observed changes at Naha and Pohaku. The gradual decay in the output of a brine phase is highlighted by measured chlorinities greater than that of bottom seawater and the order of magnitude decrease in fluid fluxes between yearly visits to each site. The flux of magmatic $\mathrm{CO}_{2}$ remains high well after the termination of vapor formation, suggesting that the two processes are decoupled at Loihi.

\subsection{Concerns for Geochemical Fluxes}

Given a global convective heat loss associated with hydrothermal processes, ratios of elemental to thermal anomalies have been used to calculate global geochemical fluxes [e.g., Edmond et al., 1979, Elderfield and Schultz, 1996]. Of great concern are those fluxes associated with low-temperature venting on ridge axes that account for significant portions of the thermal and fluid fluxes along mid-ocean ridges [Schultz and Elderfield, 1997]. While some of these low-temperature hydrothermal sites vent simple mixtures of bottom seawater and a high-temperature end-member, data from Loihi illustrate that the composition of low-temperature hydrothermal fluids can be drastically different than those of high-temperature fluids. For example, fluids from Naha have concentrations of $\mathrm{Mg}$ and sulfate that are greater than that of bottom seawater. This results in a net flux of these elements out of the crust, in contrast to fluxes from typical mid-ocean ridge hydrothermal systems. Similarly, fluxes of the alkali metals, such as $\mathrm{K}$ at Naha, may be into the crust.

The net effect of chemical fluxes from Loihi after the tectonic-volcanic event is poorly constrained because the temporal record of fluid fluxes is unknown. The one constraint that we do have is the thermal flux associated with volcanic events. This flux is limited to the heat available in the uppermost third of newly formed oceanic crust. On the basis of thermal fluxes from events on the CoAxial Segment of the Juan de Fuca Ridge, Baker et al. [1998] estimate that the thermal flux from events is only $5 \%$ of the flux from chronic venting. Thus, for these events to have an impact on global geochemical fluxes, the ratio of chemical to thermal anomalies of these venting fluids must be at least an order of magnitude greater than that measured in high-temperature black smokers (e.g., as is the case for $\mathrm{CO}_{2}$ and $\mathrm{Fe} / \mathrm{Mn}$ ), or water-rock reactions must result in chemical fluxes that are opposite to those from typical high temperature venting (e.g., $\mathrm{Mg}$, sulfate, and $\mathrm{K}$ at Naha).

Finally, the chemical composition of hydrothermal fluids from mid-ocean ridges appears to be distinct from those fluids generated by off-axis volcanism, which accounts for $\sim 20 \%$ of the yearly influx of new oceanic crust [Schilling, 1973] of which half results from intraplate volcanism [Kennett, 1982]. For example, volatile gasses play a major role in controlling the chemical composition of the fluids from Loihi, Kasuga, Macdonald, and Teahitia Seamounts [McMurtry et al., 1993; Cheminee et al., 1991; Michard et al., 1993]. At each of these sites, measured alkalinities are greater than that in bottom seawater, with the highest measured alkalinity of 31.8 $\mathrm{mmol} / \mathrm{kg}$, which is more than 3 times greater than the highest measured value in hydrothermal fluids from Loihi. In contrast, alkalinities in hydrothermal fluids from mid-ocean ridges are typically negative [Von Damm, 1995]. The high alkalinities found in non-mid-ocean ridge settings likely result from the exhalation of magmatic $\mathrm{CO}_{2}$ that enhances chemical weathering. This enhanced chemical weathering can apparently result in chemical fluxes that are not unidirectional in these systems. For example, chemical compositions of hydrothermal fluids from $\mathrm{Naha}$ result in fluxes of $\mathrm{K}, \mathrm{Mg}$, and sulfate that are either into or out of the crust.

\section{Conclusions}

Chemical data from discrete and continuous fluid samplers are presented. Each sampler has its own strengths and weaknesses. Discrete samplers provide large volume (750$\mathrm{mL}$ ) samples from which one can measure concentrations for most of the elements in the periodic table and a variety of isotopes but are restricted, even today, to those times when good weather conditions allow the use of ships and submersibles to collect samples and are limited by the amount of dive time at a given site. In contrast, OsmoSamplers provide the means to collect samples continuously and thus provide a mechanism to elucidate processes at a range of temporal scales (hours to years) and in a variety of geologic settings. Yet sample volume is limited and thus the extent of an analytical program is limited.

We have illustrated that OsmoSamplers are tools that can be used to observe chemical changes associated with tectonicvolcanic events. For example, relative to the composition of bottom seawater, the OsmoSampler at Naha Vents captured a gradual change from a hydrothermal fluid with a lower chlorinity and higher concentration of $\mathrm{K}$ to a fluid with higher chlorinity and lower concentration of $\mathrm{K}$. These changes occurred during the first 2 months of the deployment and are consistent with two or more distinct sources, one of which has a low-temperature component. The OsmoSampler at Lohiau Vents captured changes that were caused by variations in mixtures of hydrothermal sources and bottom seawater. Fluids collected by both samplers have been greatly influenced by magmatic gases and have anomalously high alkalinities. Fluids with the highest alkalinity also had the highest $\mathrm{Fe} / \mathrm{Mn}$ molar ratio, which range from 58 to 0.8 .

Unfortunately, these OsmoSamplers worked for only a portion of the time on the seafloor. In contrast to the laboratory experiments, biological activity within centimeters of the sample intakes precipitated $\mathrm{Fe}$-oxide sheaths that eventually restricted sample collection. Newly designed OsmoSamplers include in-line acidification to hinder biologically mediated $\mathrm{Fe}$ oxide formation. Additional samplers are being designed to 
obtain more frequent aliquots, to maintain in situ concentrations of dissolved gases and trace metals, and to preserve microbial community structure.

Results from Loihi illustrate that thermal and mass fluxes resulting from the 1996 event impacted the regional hydrography, but the integrated impact of these fluxes on oceanic geochemical cycles from similar events is less certain. Data from Loihi also accent our concern for including fluxes from low temperature, nonridge axis, and event sources in estimates of geochemical fluxes from hydrothermal systems. For example, fluid fluxes from event or low-temperature sources can result in chemical fluxes that are opposite to those from chronic venting on mid-ocean ridges. The composition of hydrothermal discharge from Loihi is not unique and is in many ways similar to the composition of hydrothermal discharge from other non-mid-ocean-ridge axis hydrothermal systems (e.g., rich in $\mathrm{Fe}$ and $\mathrm{CO}_{2}$ ). Additional sampling of other non-mid-ocean ridge, event, and low-temperature hydrothermal systems are required before reliable estimates of chemical fluxes associated with mid-ocean hydrothermal circulation can be adequately quantified.

Acknowledgments. This work was supported by U.S. National Science Foundation (grant OCE93-14393 to C.G.W. and F.J.S.), NOAA's National Undersea Research Program, the Hawaii Undersea Research Laboratory, and the Monterey Bay Aquarium Research Institute. This paper benefitted from many discussions with $\mathrm{D}$. Clague and reviews from M. K. Tivey, D. Butterfield, and E. Klein. Global Undersea Research Unit contribution 103. SOEST contribution 4968.

\section{References}

Alt, J. C., D. Teagle, C. Laverne, D. Vanko, W. Bach, J. Honnorez, K. Becker, M. Ayadi, and P. A. Pezard, Ridge flank alteration of upper ocean crust in the eastern Pacific: Synthesis of results fro volcanic rocks of Holes 504B and 896A, Proc. Ocean Drill. Program, Sci. Results, 148, 435-450, 1996.

Baker, E. T., G. J. Massoth, and R. A. Feely, Cataclysmic hydrothermal venting on the Juan de Fuca Ridge, Nature, 329, 149-151, 1987.

Baker, E. T., G. J. Massoth, R. A. Feely, G. A. Cannon, and R. E. Thomson, The rise and fall of the CoAxial hydrothermal site, 19931996, J. Geophys. Res., 103, 9791-9806, 1998.

Bischoff, J. L., and R. J. Rosenbauer, Liquid-vapor relations in the critical region of the system $\mathrm{NaCl}-\mathrm{H}_{2} \mathrm{O}$ from 380 to $415^{\circ} \mathrm{C}$ : A refined determination of the critical point and two-phase boundary of seawater, Geochim. Cosmochim. Acta, 52, 2121-2126, 1988.

Bischoff, J. L., and R. J. Rosenbauer, The alteration of rhyolite in $\mathrm{CO}_{2}$ charged water at 200 and $350^{\circ} \mathrm{C}$ : The unreactivity of $\mathrm{CO}_{2}$ at higher temperatures, Geochim. Cosmochim. Acta, 60, 3859-3867, 1996.

Butterfield, D.A., and G. J. Massoth, Geochemistry of north Cleft segment vent fluids: Temporal changes in chlorinity and their possible relation to recent volcanism, J. Geophys. Res., 99, 49514968, 1994.

Butterfield, D. A., G. J. Massoth, R. E. McDuff, J. E. Lupton, and M. D. Lilley, Geochemistry of hydrothermal fluids from Axial Seamount hydrothermal emissions study vent field, Juan de Fuca Ridge: Subseafloor boiling and subsequent fluid-rock interactions, J. Geophys. Res., 95, 12,895-12,921, 1990.

Butterfield, D. A., I. R. Jonasson, G. J. Massoth, R. A. Feely, K. K. Roe, R. E. Embley, J. F. Holden, R. E. McDuff, M. D. Lilley, and J. R. Delaney, Seafloor eruptions and evolution of hydrothermal fluid chemistry, Philos. Trans. R. Soc. London, Ser. A, 355, 369386, 1997

Cheminee, J. L., P. Stoffers, G. McMurtry, H. Richnow, D. Puteanus, and P. Sedwick, Gas-rich submarine exhalations during the 1989 enuption of Macdonald Seamount, Earth Planet. Sci. Lett., 107, 318-327, 1991.

Chevaldonne, P., D. Desbruyeres, and M. Le Haitre, Time-series of temperature from three deep-sea hydrothermal vent sites, Deep Sea Res., 38, 1417-1430, 1991 .
Davis, A. S., and D. A. Clague, Changes in the hydrothermal system at Loihi Seamount after the formation of Pele's Pit in 1996, Geology, 26, 399-402, 1998.

De Carlo, E. H., G. M. McMurtry, and H.-W. Yeh, Geochemistry of hydrothermal deposits from Loihi submarine volcano, Hawaii, Earth Planet Sci. Lett., 66, 438-449, 1983.

Delaney, J. R., D. S. Kelley, M. D. Lilley, D. A. Butterfield, J. A. Baross, W. S. D. Wilcock, R. W. Embley, and M. Summit, The quantum event of oceanic crustal accretion: Impacts of diking at mid-ocean ridges, Science, 281, 222-230, 1998.

Ding, K., and W. E. Seyfried Jr., Determination of Fe-Cl complexing in the low pressure supercritical region ( $\mathrm{NaCl}$ fluid): Iron solubility constraints on $\mathrm{pH}$ of subseafloor hydrothermal fluids, Geochim. Cosmochim. Acta, 56, 3681-3692, 1992.

Edmond, J. M., C. Measures, R. E. McDuff, L. H. Chan, R. Collier, B. Grant, L. I. Gordon, and J. B. Corliss, Ridge crest hydrothermal activity and the balances of the major and minor elements in the ocean: The Galapagos data, Earth Planet. Sci. Lett., 46, 1-18, 1979.

Edmond, J. M., A. C. Campbell, M. R. Palmer, K. K. Falkner, and T. S. Bowers, Chemistry of low temperature fluids from Loihi and Larson's Seamounts (abstract), Eos Trans. $A G U, 68,1553-1554$, 1987.

Elderfield, H., and A. Schultz, Mid-ocean ridge hydrothermal fluxes and the chemical composition of the oceans, Annu. Rev. Earth Planet. Sci., 24, 191-224, 1996.

Elderfield, H., C. G. Wheat, M. J. Mottl, C. Monnin, B. Spiro, Fluid and geochemical transport through oceanic crust: A transect across the eastem flank of the Juan de Fuca Ridge. Earth Planet. Sci. Lett., 172, 151-169, 1999.

Emerson, D., and C. L. Moyer, Isolation and characterization of novel iron-oxidizing bacteria that grow at circumneutral $\mathrm{pH}, \mathrm{Appl}$. Environ. Microbiol., 63, 4784-4792, 1997.

Fomari, D. J., T. Shank, K. L. Von Damm, T. K. P. Gregg, M. Lilley, G. Levai, A. Bray, R. M. Haymon, M. R. Perfit, and R. Lutz, Timeseries temperature measurements at high-temperature hydrothermal vents, East Pacific Rise $9^{\circ} 49^{\prime}-51^{\prime} \mathrm{N}$ : Evidence for monitoring a crustal cracking event, Earth Planet. Sci. Lett., 160, 419-431, 1998.

Frey, F. A., and D. A. Clague, Geochemistry of diverse basalt types from Loihi Seamount, hawaii: pertogenetic implications, Earth Planet. Sci. Lett., 66, 337-355, 1983.

Gamo, T., J.-I. Ishibashi, H. Sakai, and B. Tilbrook, Methane anomalies in seawater above Loihi seamount summit area, Hawaii, Geochim. Cosmochim. Acta, 51, 2857-2864, 1987.

Gerlach, T. M., and E. J. Graeber, Volatile budget of Kilauea volcano, Nature, 313, 273-277, 1985.

Hilton, D. R., G. M. McMurtry, and F. Goff, Large variations in vent fluid $\mathrm{CO}_{2}{ }^{3} \mathrm{He}$ ratios signal rapid changes in magma chemistry at Loihi Seamount, Hawaii, Nature, 396, 359-362, 1998.

Jannasch, H. W., K. S. Johnson and C. M. Sakamoto, Submersible, osmotically pumped analyzers for continuous determination of nitrate in situ, Anal. Chem. 66, 3352-3361, 1994.

Karl, D. M., G. M. McMurtry, A. Malahoff, and M. O. Garcia, Loihi Seamount, Hawaii: A mid-plate volcano with a distinctive hydrothermal system, Nature, 335, 532-535, 1988.

Kennett, J., Marine Geology, Prentice-Hall, Englewood Cliffs, N. J., 1982.

Landsteiner, M.C., C. G. Wheat, Y. C. Yuan, J. A. Resing, and E. A. McLaughlin, Hydrothermal plumes above the summit of Loihi Seamount, Hawaii, Eos Trans. AGU, 74 (43), Fall Meet. Suppl., 361, 1993.

Mackenzie, F. T., and R. M. Garrels, Chemical mass balance between rivers and oceans, $A m$. J. Sci., 264, 507-525, 1966.

Malahoff, A., G.M. McMurtry, J.C. Wiltshire, and H.-W. Yeh, Geology and chemistry of hydrothermal deposits from active submarine volcano Loihi, Hawaii, Nature, 298, 234-239, 1982.

Massoth, G. J., D. A. Butterfield, J. E. Lupton, R. E. McDuff, M. D. Lilley, and I. R. Jonasson, Submarine venting of phase-separated hydrothermal fluids at Axial volcano, Juan de Fuca Ridge, Nature, 340, 702-705, 1989.

Massoth, G. J., E. T. Baker, R. A. Feely, D. A. Butterfield, R. E. Embley, J. E. Lupton, R. E. Thomson, and G. A. Cannon, Observations of manganese and iron at the CoAxial seafloor eruption site, Juan de Fuca Ridge, Geophys. Res. Lett., 22, 151-154, 1995. 
Massoth, G. J., E. T. Baker, R. A. Feely, J. E. Lupton, R. W. Collier, J. F. Gendron, K. K. Roe, S. M. Maenner, and J. A. Resing, Manganese and iron in hydrothermal plumes resulting from the 1996 Gorda Ridge event, Deep Sea Res., 45, 2683-2712, 1998.

McMurtry, G. M., P.N. Sedwick, P. Fryer, D. L. VonderHaar, and H.W. Yeh, Unusual geochemistry of hydrothermal vents on submarine arc volcanoes: Kasuga Seamounts, northern Mariana Arc, Earth Planet. Sci. Lett., I14, 517-528, 1993.

Michard, A., G. Michard, D. Stuben, P. Stoffers, J.-L. Cheminee, and N. Binard, Submarine thermal springs associated with young volcanoes: The Teahitia vents, Society Islands, Pacific Ocean, Geochim. Cosmochim. Acta, 57, 4977-4986, 1993.

Moyer, C. L., F. C. Dobbs, and D. M. Karl, Estimation of diversity and community structure through restriction fragment length polymorphism distribution analysis of bacterial 16S rRNA genes from a microbial mat at an active, hydrothermal vent system, Loihi Seamount, Hawaii. Appl. Environ. Microbiol., 60, 871-879, 1994.

Moyer, C. L., F. C. Dobbs, and D. M. Karl, Phylogenetic diversity of the bacterial community from a microbial mat at an active, hydrothermal vent system, Loihi Seamount, Hawaii. Appl. Environ. Microbiol., 6I, 1555-1562, 1995.

Resing, J. A., and F. J. Sansone, The chemical signature of lavaseawater interactions: The generation of acidity, Geochim. Cosmochim. Acta, 63, 2183-2198, 1999.

Sakai, H., et al., Hydrothermal activity on the summit of Loihi Seamount, Hawaii, Geochem. J., 21, 11-21, 1987.

Sansone, F. J., C. G. Wheat, G. M. McMurtry, J. E. Lupton, G. P. Klinkhammer, Geochemistry of $\mathrm{CO}_{2}$-rich hydrothermal vent fluids and plumes from Loihi Seamount, Eos Trans. $A G U, 75$ (44), Fall Meet. Suppl., 313, 1994.

Sansone, F. J., B. P. Midson, C. G. Wheat, J. A. Resing, C. L. Moyer, and $H$. W. Jannasch, Geochemical evolution of Loihi Seamount following the 1996 seismic event, Eos Trans. $A G U, 79$ (45), Fall Meet. Suppl., F1022, 1998.

Schilling, J. G., Iceland mantle plume: Geochemical evidence along the Reykjanes Ridge, Nature, 242, 565-571, 1973.

Schultz, A., and H. Elderfield, Controls on the physics and chemistry of seafloor hydrothermal circulation, Philos. Trans. R. Soc. London, Ser. A, 355, 387-425, 1997.

Schultz, A., J. R. Delaney, and R. E. McDuff, On the partitioning of heat flux between diffuse and point source seafloor venting, $J$. Geophys. Res., 97, 12,299-12,314, 1992.

Sedwick, P. N., G. M. McMurtry, and J. D. Macdougall, Chemistry of hydrothermal solutions from Pele's Vents, Loihi Seamount, Geochim. Cosmochim. Acta, 56, 3643-3667, 1992.

Sedwick, P. N., G. M. McMurtry, D. Hilton, and F. Goff, Carbon dioxide and helium in hydrothermal fluids from Loihi Seamount, Hawaii, USA: Temporal variability and implications for the release of mantle volitiles, Geochim. Cosmochim. Acta, 58, 1219-1227, 1994.

Seyfried, W. E., Jr., and J. L. Bischoff, Low temperature basalt alteration by seawater: An experimental study at $70^{\circ} \mathrm{C}$ and $150^{\circ} \mathrm{C}$, Geochim. Cosmochim. Acta, 43, 1937-1947, 1979.

Seyfried, W. E., Jr., and M. J. Mottl, Hydrothermal alteration of basalt by seawater under seawater-dominated conditions, Geochim. Cosmochim. Acta, 46, 985-1002, 1982.
Seyfried, W. E., Jr., M. E. Berndt, and D. R. Janecky, Chloride depletions and enrichments in seafloor hydrothermal fluids: Constraints from experimental basalt alteration studies, Geochim Cosmochim Acta, 50, 469-475, 1986.

Shanks, W. C., J. K. Bohlke, and R. R. Seal, Stable isotopes in midocean ridge hydrothermal systems: Interactions between fluids, minerals, and organisms, Seafloor Hydrothermal Systems: Physical, Chemical, Biological, and Geological Interactions, Geophys. Monogr. Ser., vol. 91, edited by S. Humphris et al., pp. 194-221, AGU, Washington, D.C., 1995.

The 1996 Loihi Science Team, Researchers rapidly respond to submarine activity at Loihi Volcano, Hawaii, Eos Trans. $A G U, 78$, 229, 232-233, 1997.

Theeuwes, F., and S. I. Yum, Principles of the design and operation of generic osmotic pumps for the delivery of semisolid or liquid drug formulations, Ann. Biomed. Eng., 4, 343-353, 1976.

Tivey, M. K., L. O. Olson, V. W. Miller, and R. D. Light, Temperature measurements during initiation and growth of a black smoker chimney, Nature, 346, 51-54, 1990.

Von Damm, K. L., Controls on the chemistry and temporal variability of seafloor hydrothermal fluids, Seafloor Hydrothermal Systems: Physical, Chemical, Biological, and Geological Interactions, Geophys. Monogr. Ser., vol. 91, edited by S. Humphris et al., pp. 222-247, AGU, Washington, D.C., 1995.

Von Damm, K. L., S. E. Oosting, R. Kozlowski, L. G. Buttermore, D. C. Colodner, H. N. Edmonds, J. M. Edmond, and J. M. Grebmeier, Evolution of East Pacific Rise hydrothermal fluids following an oceanic eruption, Nature, 375, 47-50, 1995.

Von Damm, K. L., L. G. Buttermore, S. E. Oosting, A. M. Bray, D. J. Fornari, M. D. Lilley, and W. C. Shanks III, Direct observation of the evolution of a seafloor 'black smoker' from vapor to brine, Earth Planet. Sci. Lett., 149, 101-111, 1997.

Walther, J. V., and H. C. Helgeson, Calculation of the thermodynamic properties of aqueous silica and the solubility of quartz and its polymorphs at high pressures and temperatures, Am. J. Sci., 277, 1315-1351, 1977.

Wheat, C. G., and M. J. Mottl, Composition of pore and spring waters from Baby Bare: Global implications of geochemical fluxes from a ridge flank hydrothermal system. Geochim. Cosmochim. Acta, 64, 629-642, 2000.

H. W. Jannasch and J. N. Plant, Monterey Bay Aquarium Research Institute, 7700 Sandholdt Road, P. O. Box 628, Moss Landing, CA 95039. (jaha@mbari.org) (jplant@mbari.org)

G. M. McMurtry and F. J. Sansone, Department of Oceanography, SOEST, 1000 Pope Road, University of Hawaii, Honolulu, HI 96822. (garym@soest.hawaii.edu) (sansone@soest.hawaii.edu)

C. L. Moyer, Biology Department, Western Washington University, Bellingham, WA 98225. (cmoyer@fire.biol.wwu.edu)

C. G. Wheat, West Coast NURC, P.O. Box 475, Moss Landing, CA 95039. (wheat@mbari.org)

(Received February 8, 1999; revised January 14, 2000; accepted March 15, 2000.) 